\title{
الأنساق الثقافية المضمرة وتحديات الأدب النسوي في المجتمعات العربية مواجهة الذات في ديوان (مرة حلمت لمريم خليفة أنموذجا
}

د. أحمد يوسف عزت

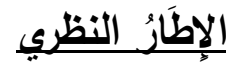

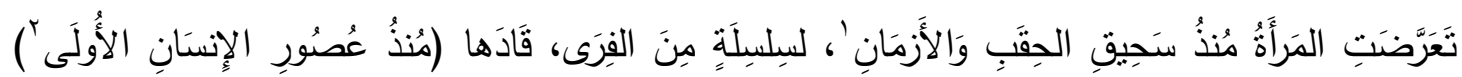

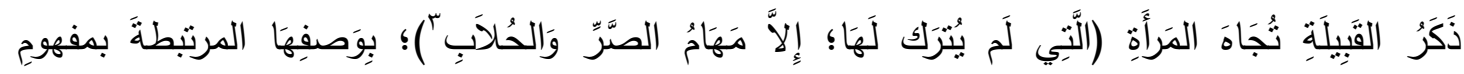

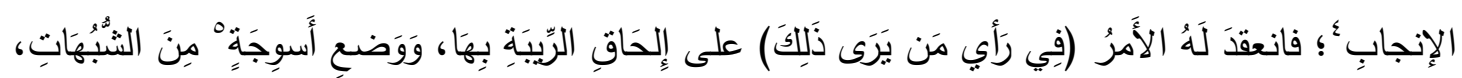

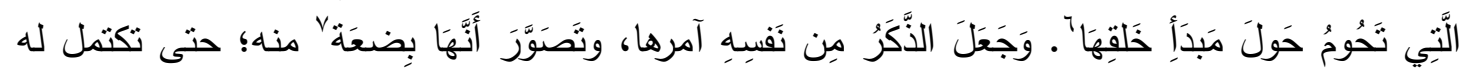

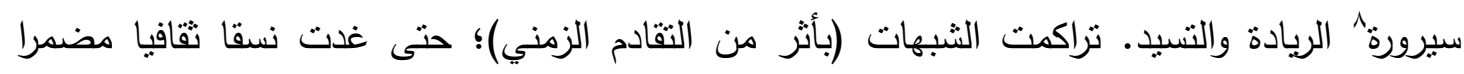

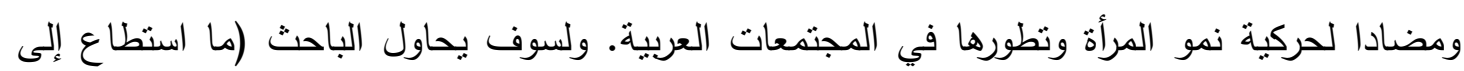

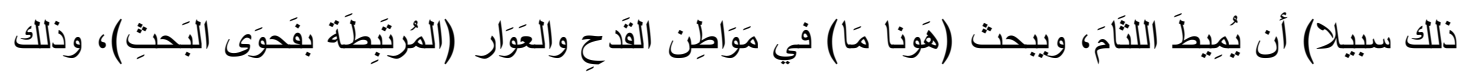

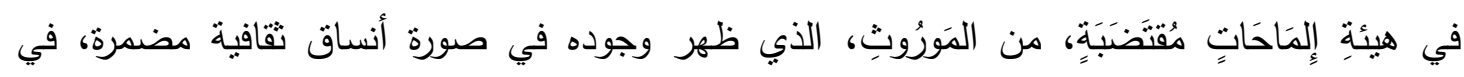

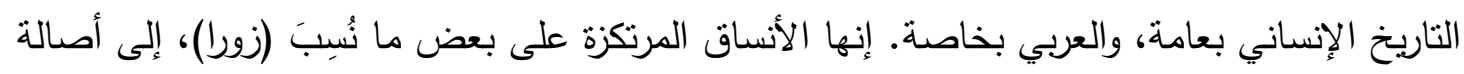

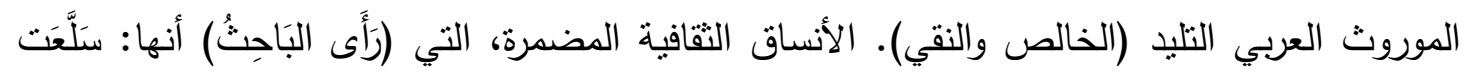

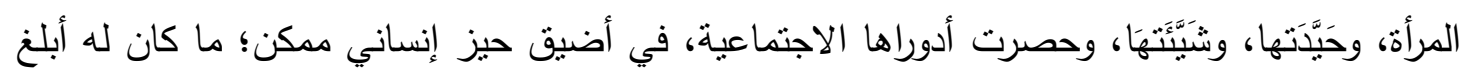
الأثر في تحديات دورها الأدبي الإبداعي في المجتمعات العربية.

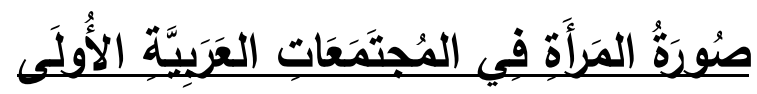

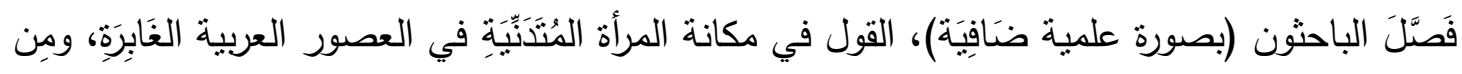

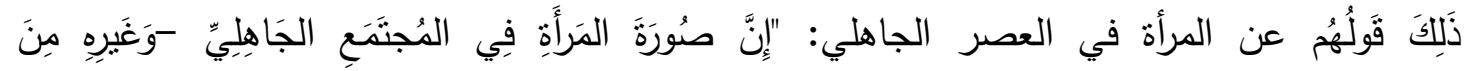

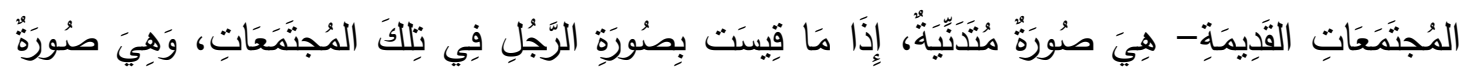

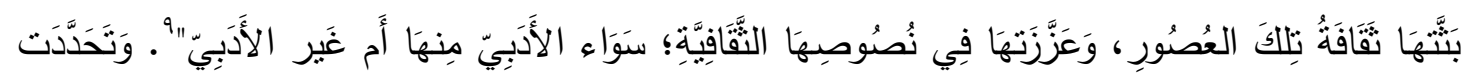

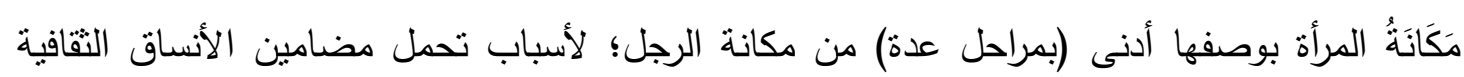

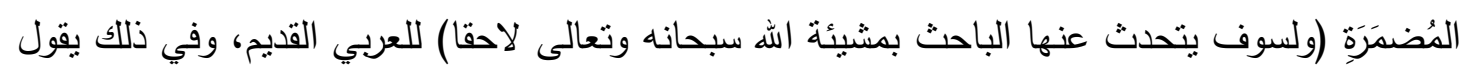

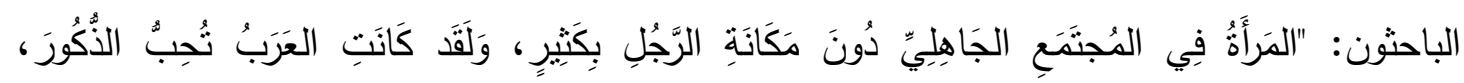

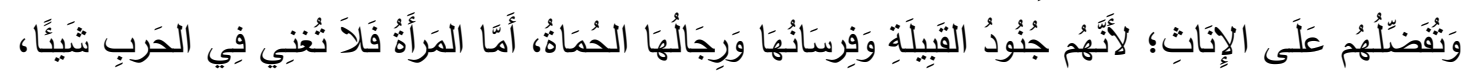

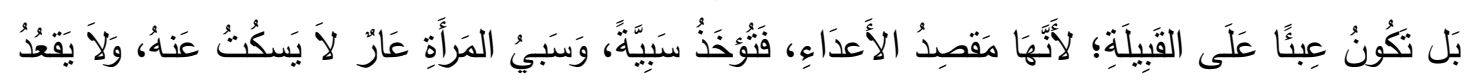

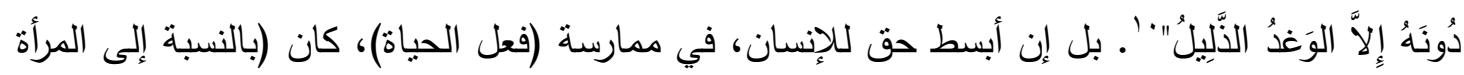

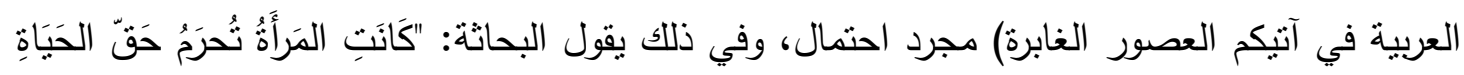

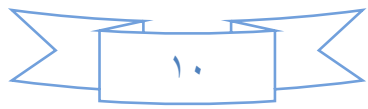




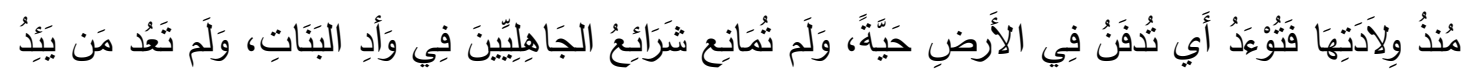

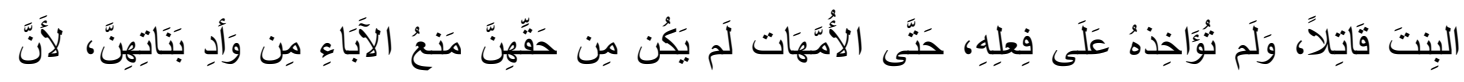

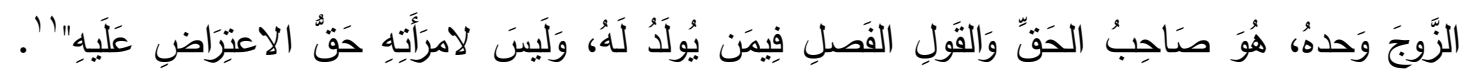

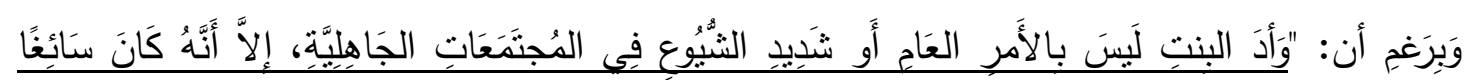

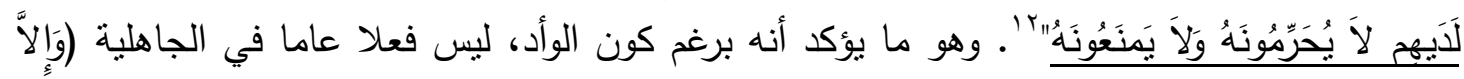

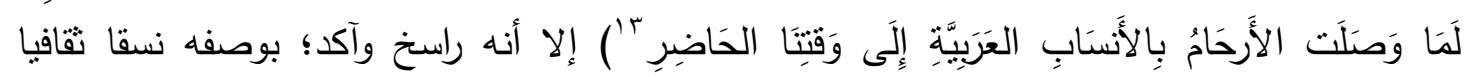

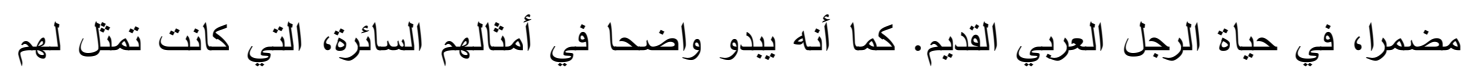

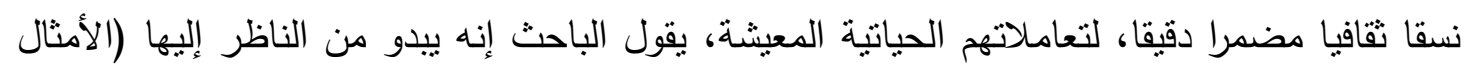

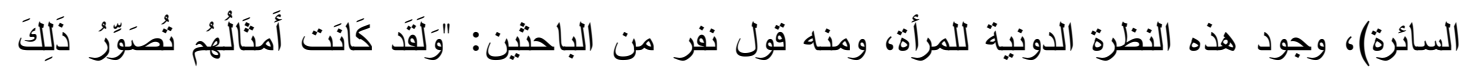

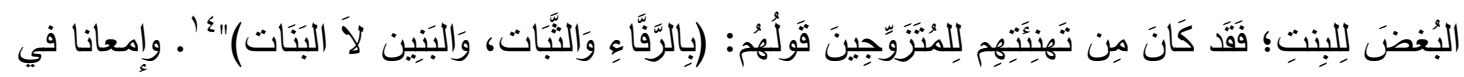

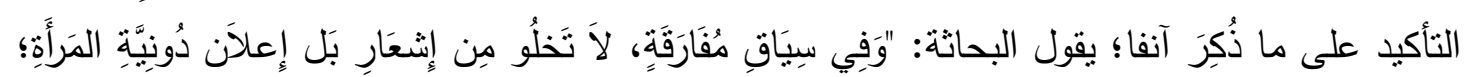

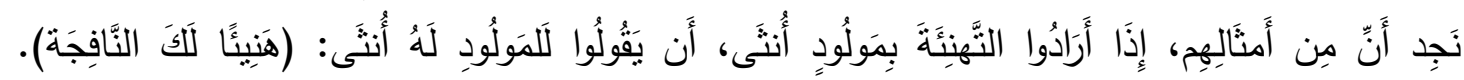

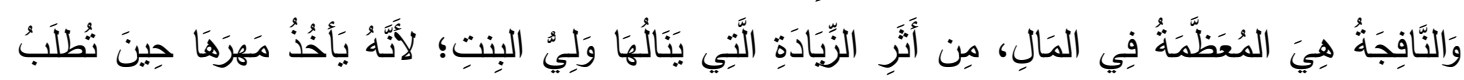

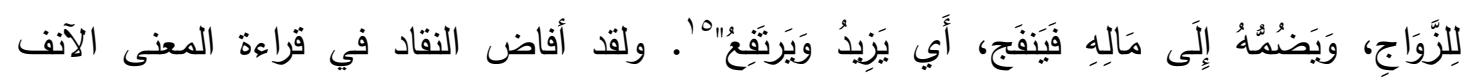

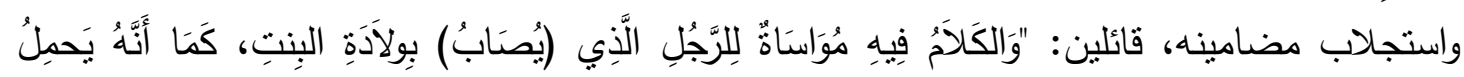

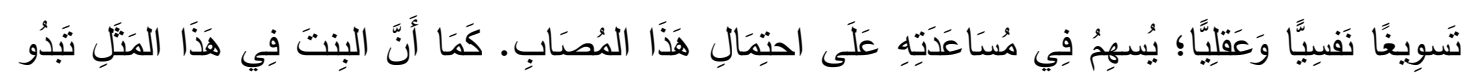

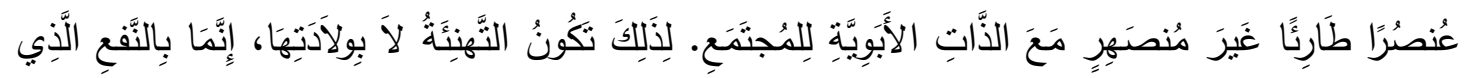

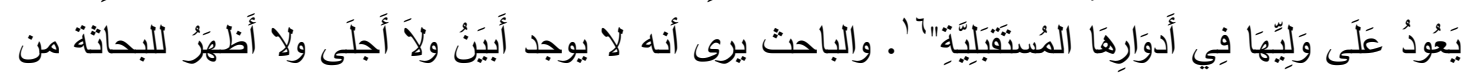

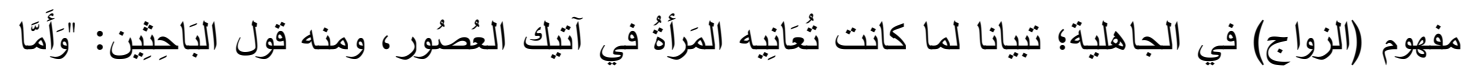

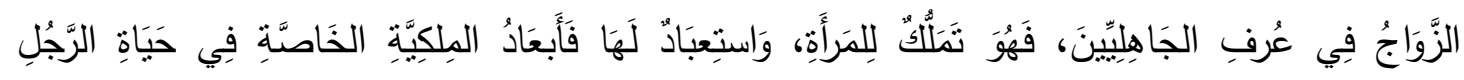

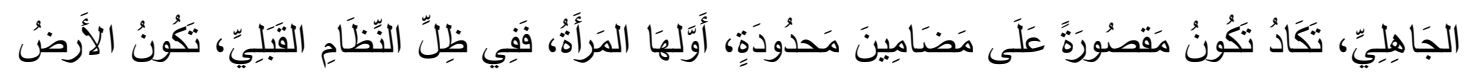

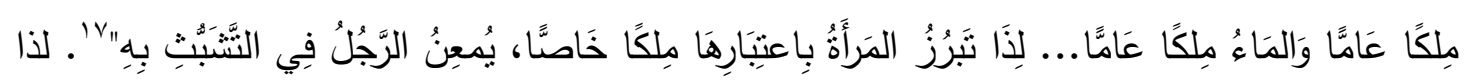

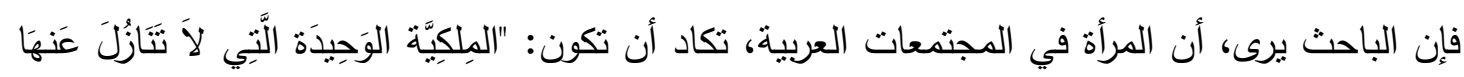

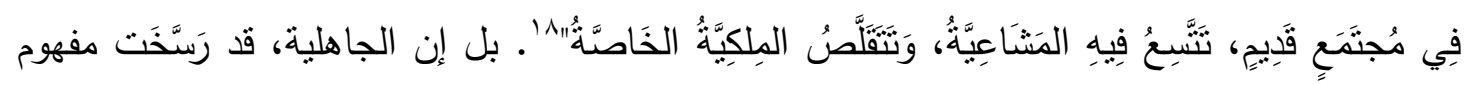

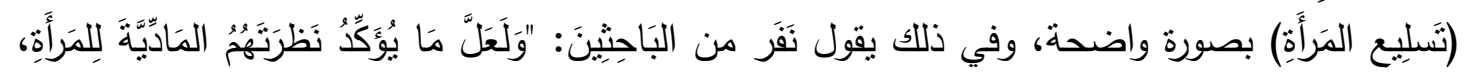

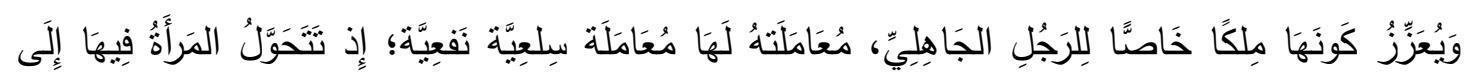

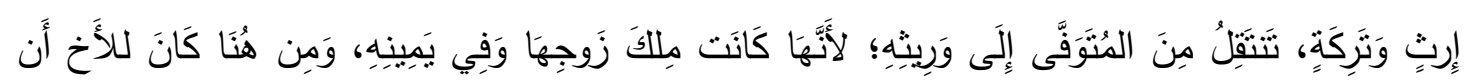

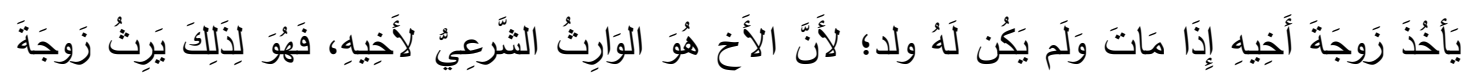

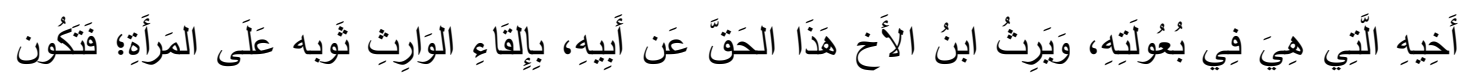

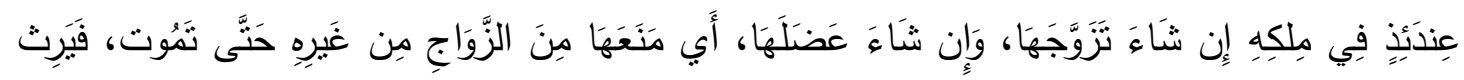

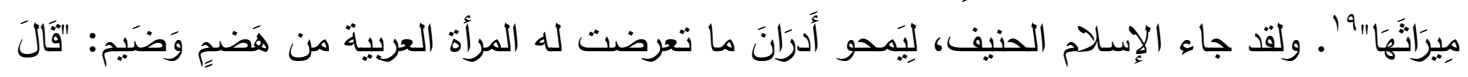

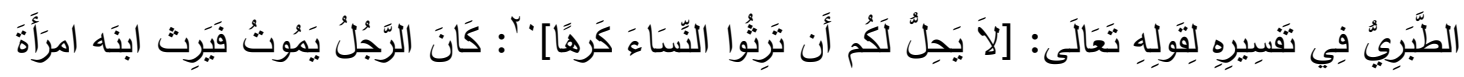

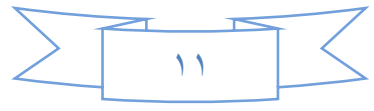




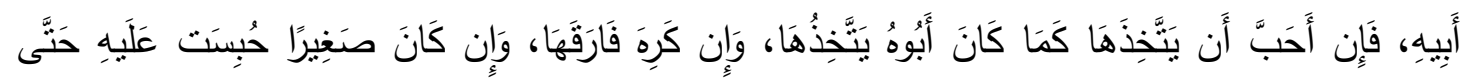

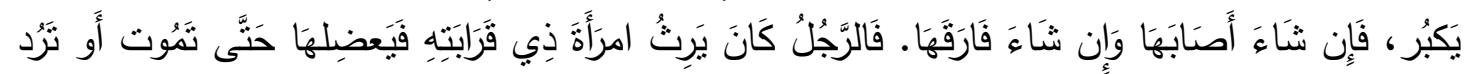

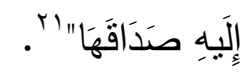

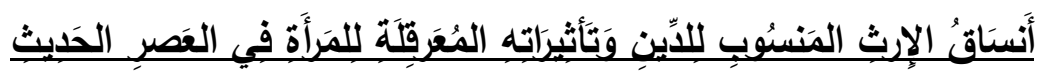

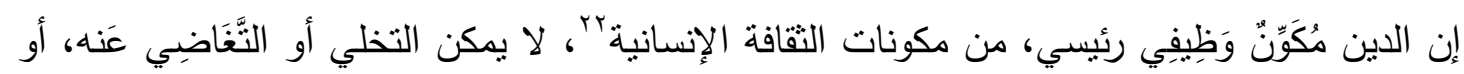

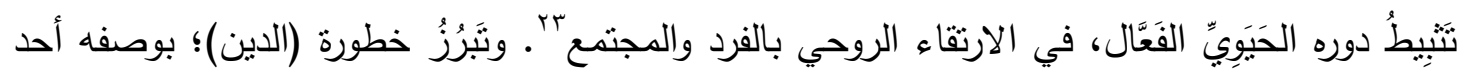

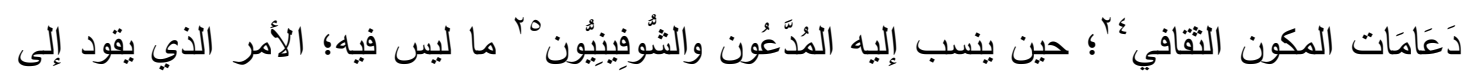

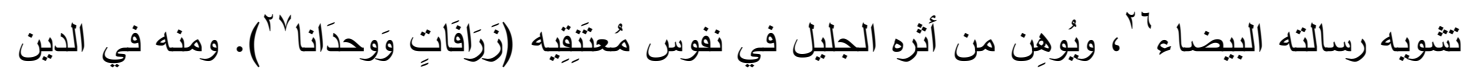

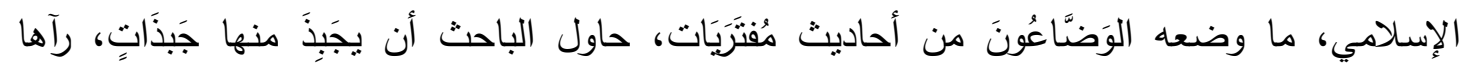

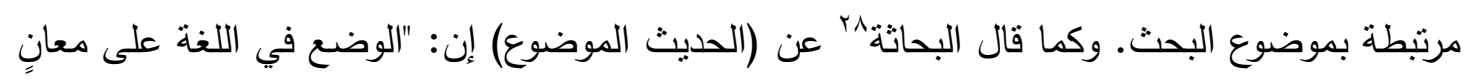

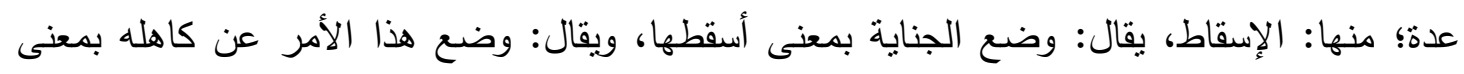

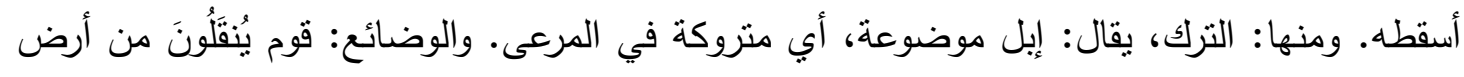

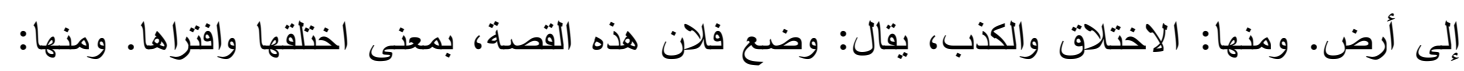

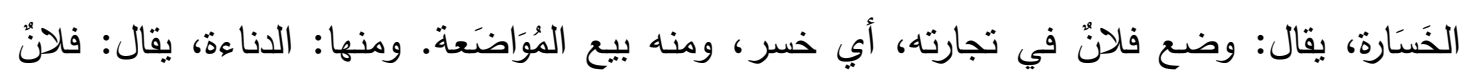

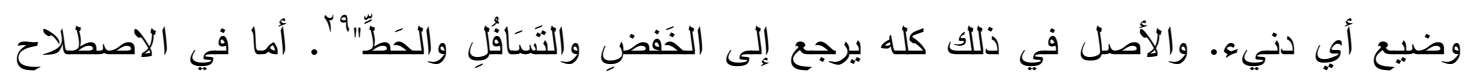

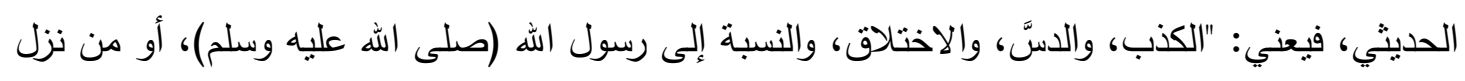

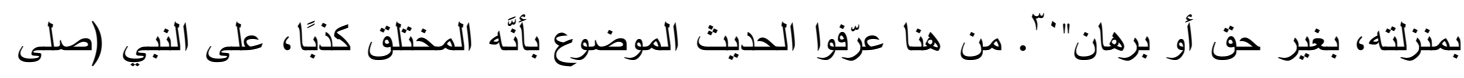

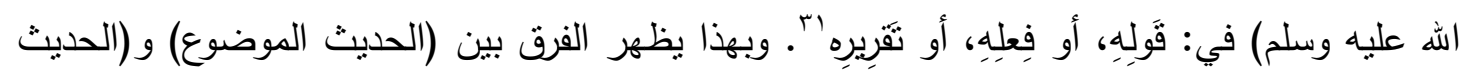

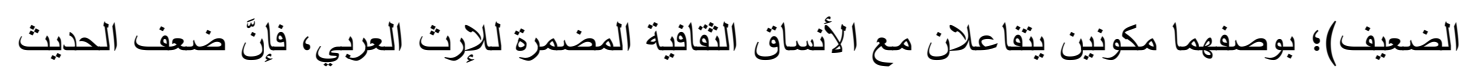

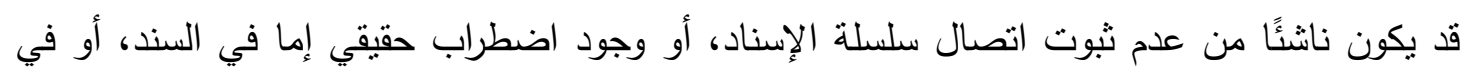

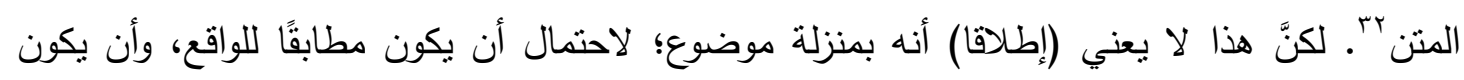

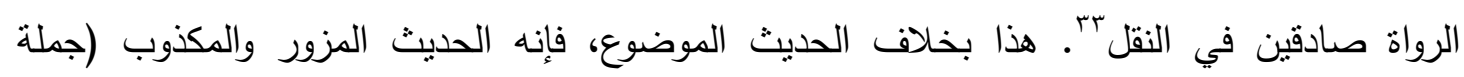

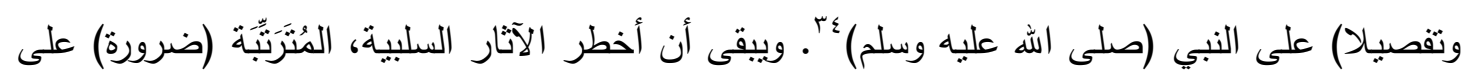

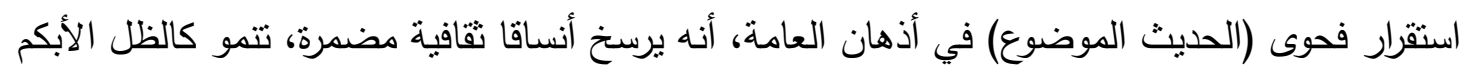

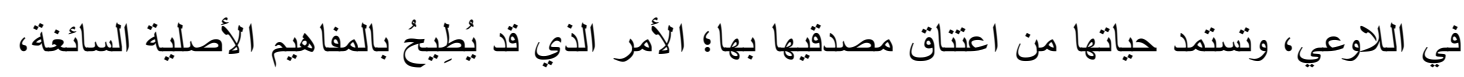

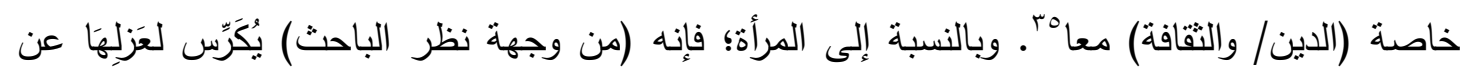

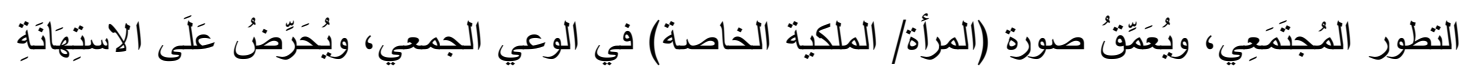

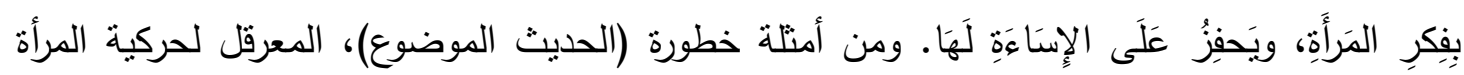
العربية في المجتمع، الآتي بيانه: الإني

1- نسق ثقافي مضمر: يعرقلها عن حقها في التعليم والتثقيف والاستتارة، يختفي في الترَوِيّ (زورا)

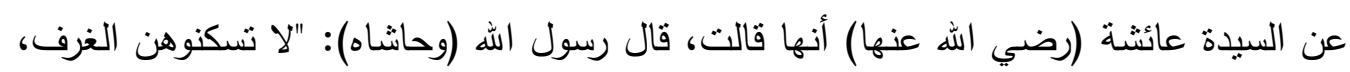

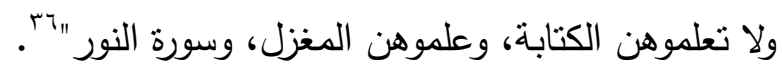




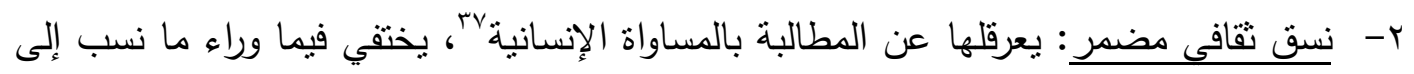

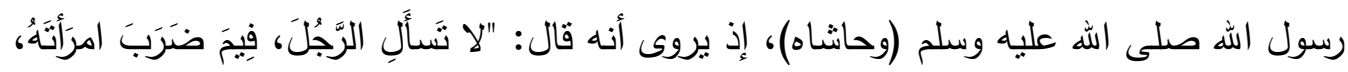

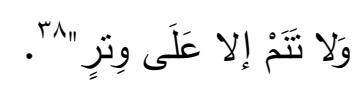

r- نسق ثقافى مضمر: يعرقلها عبر اتخاذ الداء أساسا للمفاضلة، ويختفي وراء اعتبار الصحة

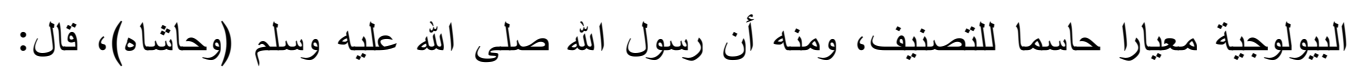

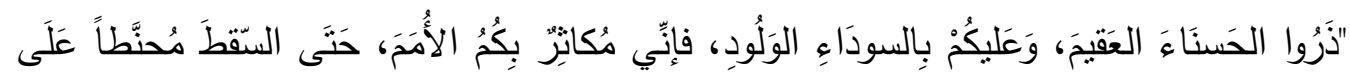

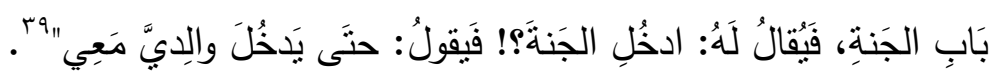

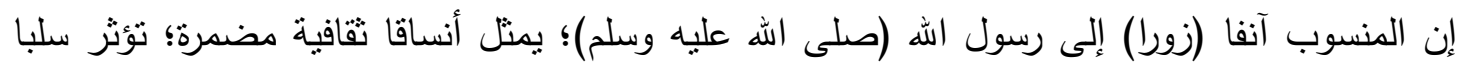

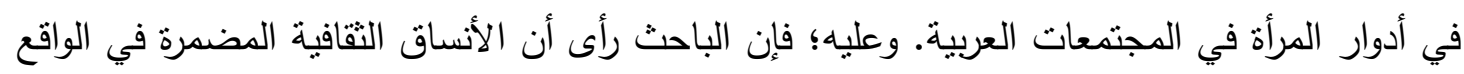

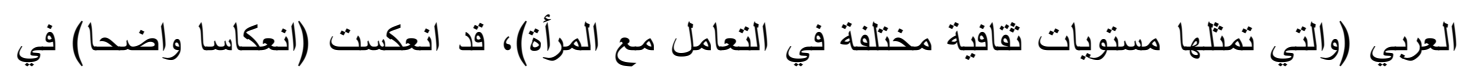

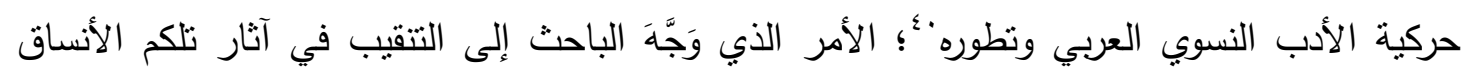

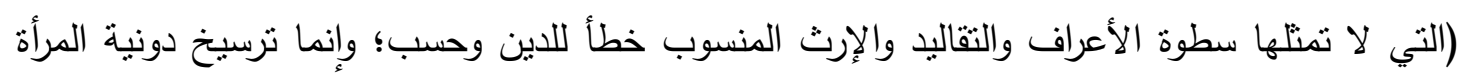

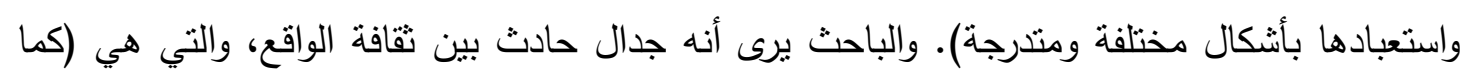

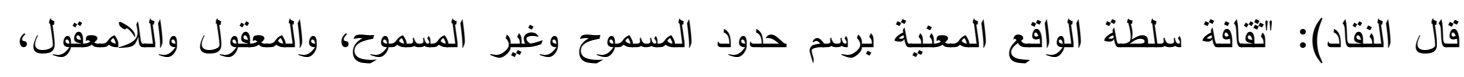

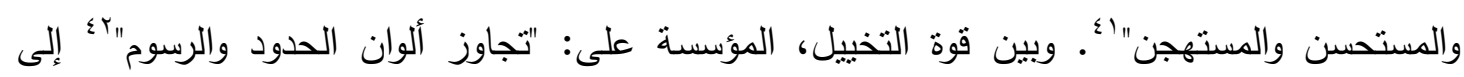

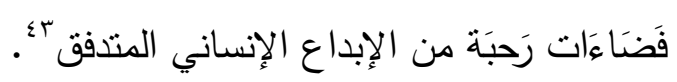

\section{مَفْهُومُ النَّستَّق}

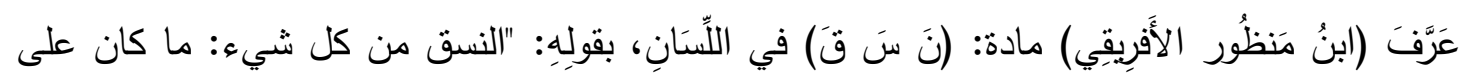

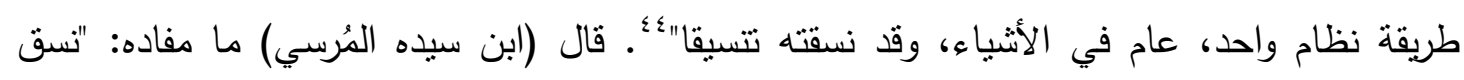

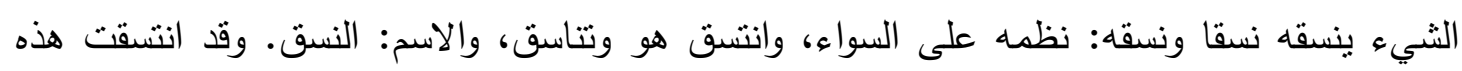

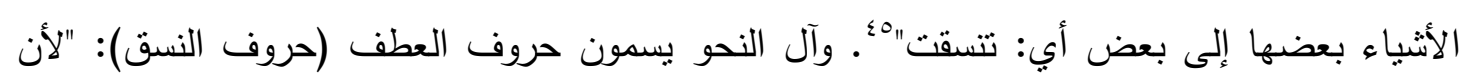

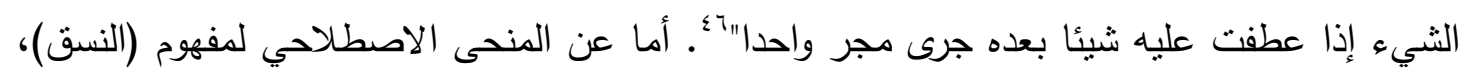

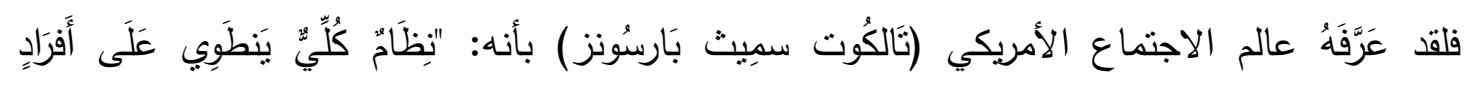

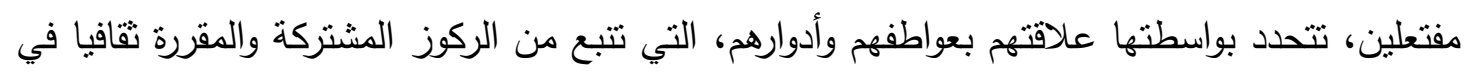

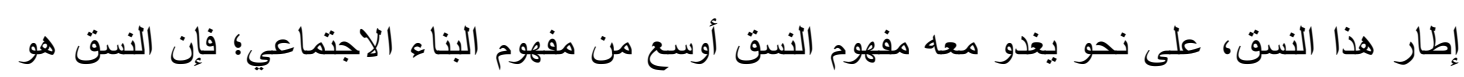

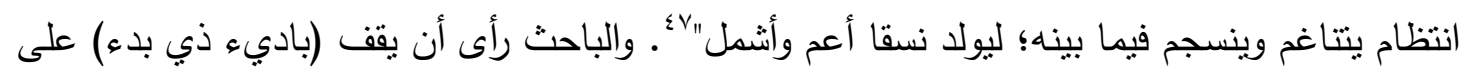

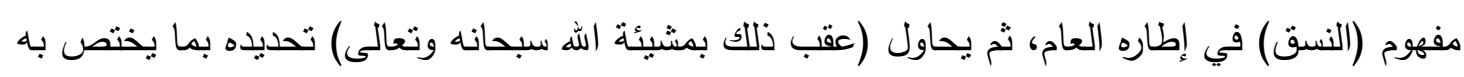

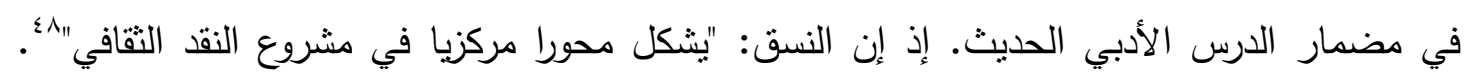

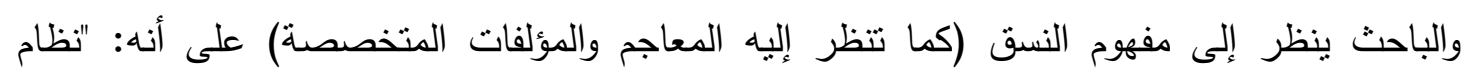

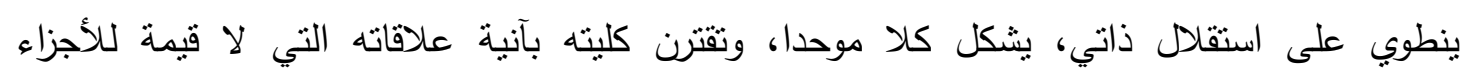

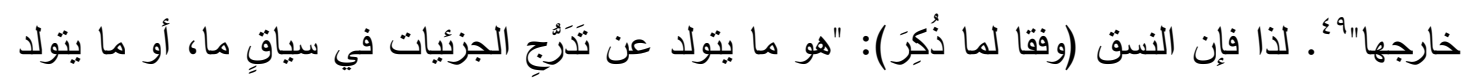

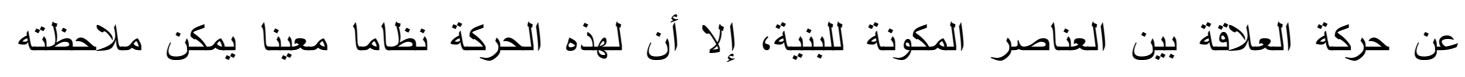

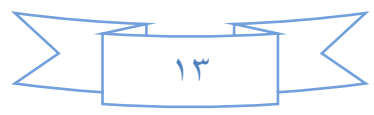




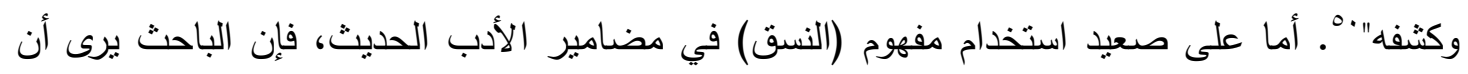

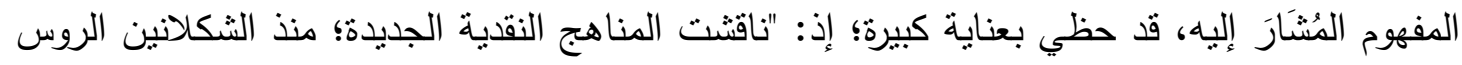

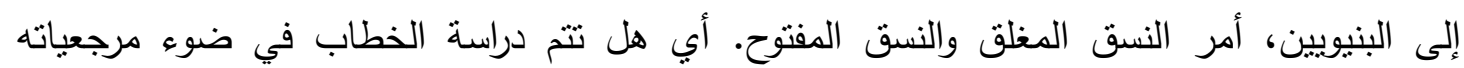

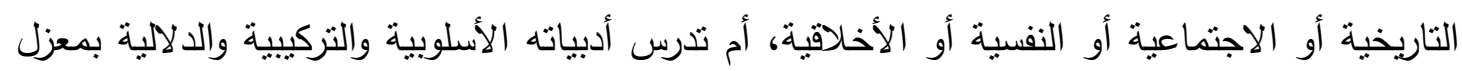

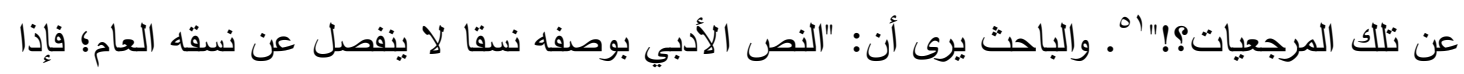

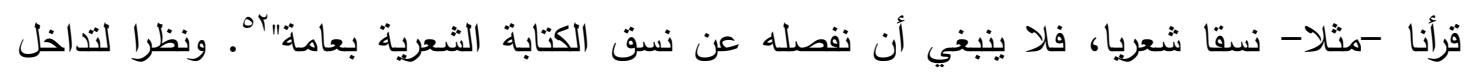

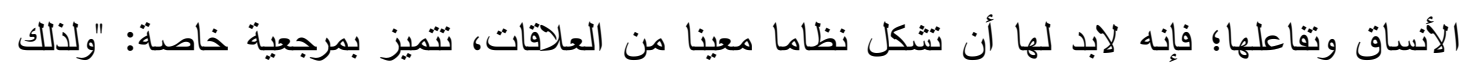

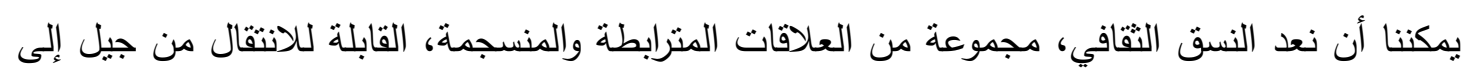

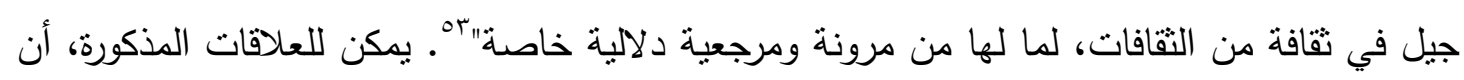

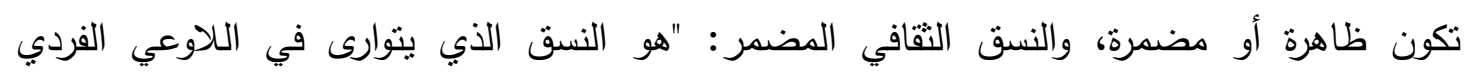

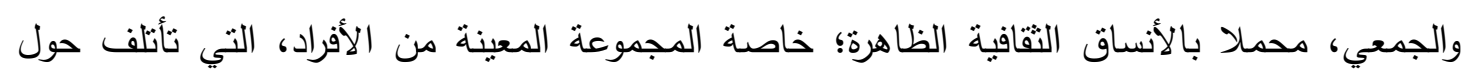

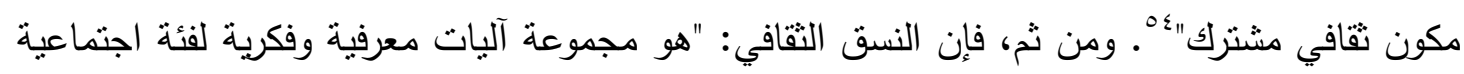

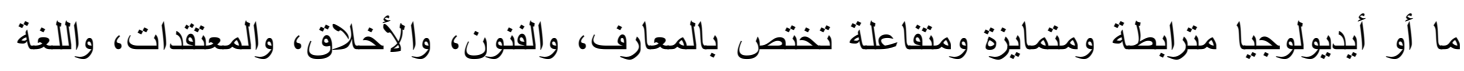

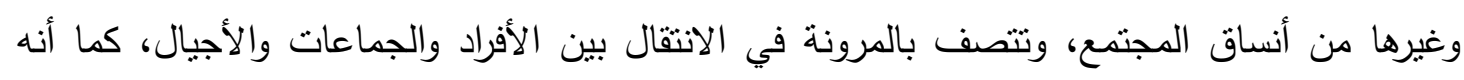

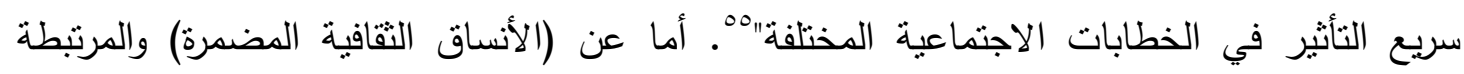

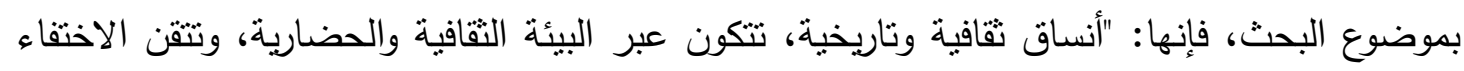

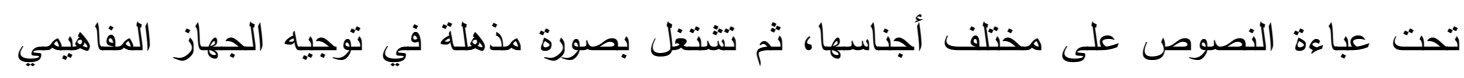

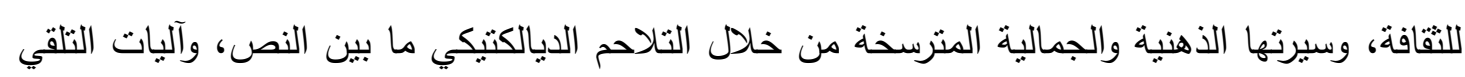

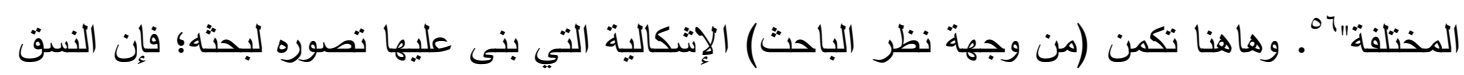

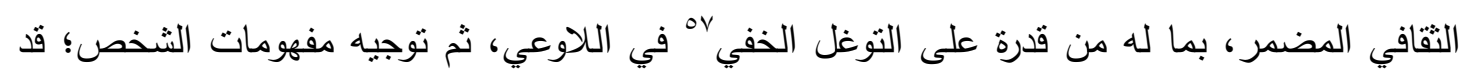

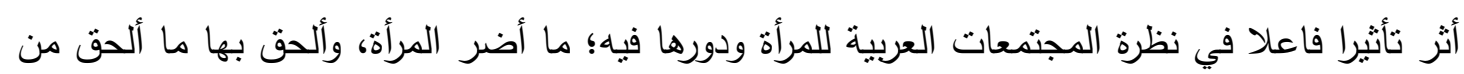

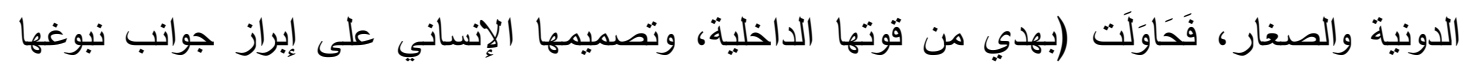

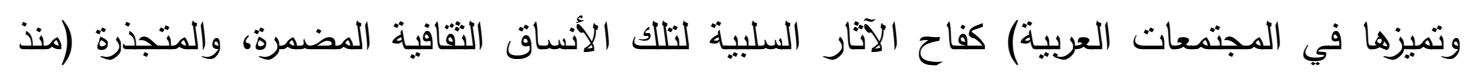

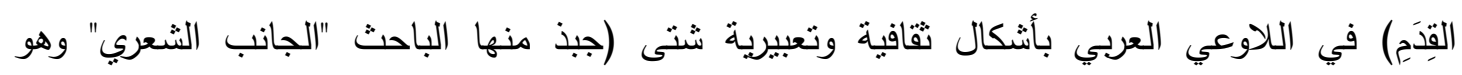

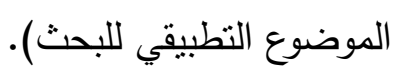

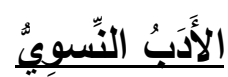

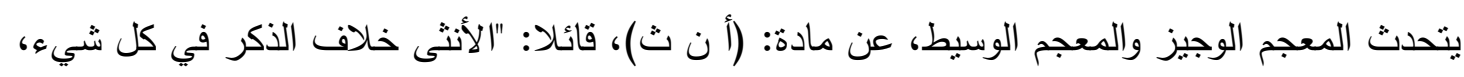

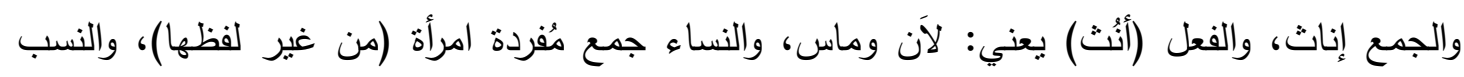

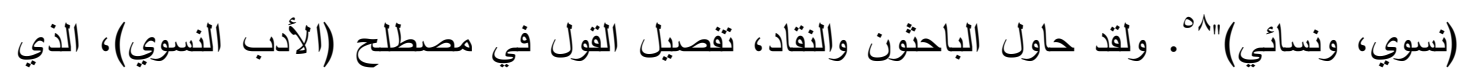

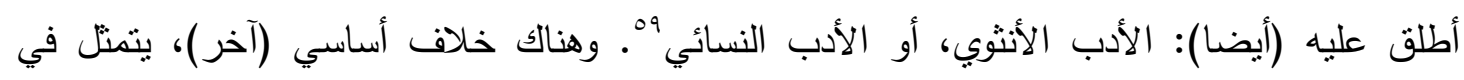

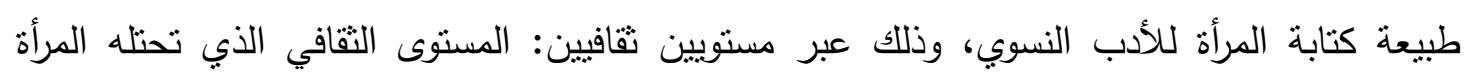

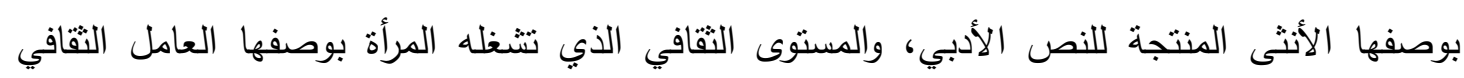

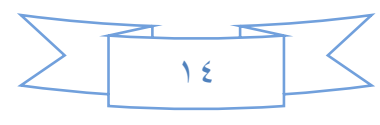


المتدفق، أي التي يصدر نصها الأدبي من معين الأنساق التقافية للمجتمعات العربية، والتي اكتسبتها (المرأة المذكورة) من البيئة المحيطة داخليا وخارجيا.”. ولسوف بعتمد الباحث (بمشيئة الله سبحانه وتعالى) على المستوبين الثقافيين للمرأة الثاعرة في المجتمع العربي؛ بوصفهما المؤكدين لما بريد الباحث أن يثتبه من خلال بحثث.

منتهَاجُ البَحِث اعتمد الباحث (الذي يناقش في بحثه الأنساق الثقافية المضمرة وتحديات الأدب النسوي) على آليات منهج (النقد الثقافي)، وهو المنهج: "الذي يحلل النصوص والخطابات الأدبية والفنية والجمالية، في ضوء معايير ثقافية واجتماعية وأخلاقية، بعيدا عن المعايير الجمالية والفنية والبوبطيقية" ". وعليه، فإن منهج

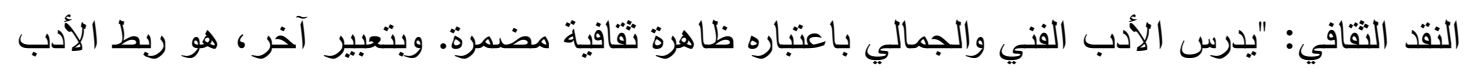
بسياقه التقافي غير المعلن" ". ومن ثم، فإن النقد النقافي: "لا يتعامل مع النصوص والخطابات الجمالية والفنية على أنها رموز جمالية ومجازات شكلية موحية، بل على أنها أنساق ثقافية مضمرة، تعكس مجموعة من السياقات الثقافية التاريخية والاجتماعية والاقتصادية والأخلاقية والقيم الحضارية والإنسانية" آت. وبناء على ما تقدم، فإن منهج (النقد الثقافي) البحثي: "يتعامل مع الأدب الجمالي ليس

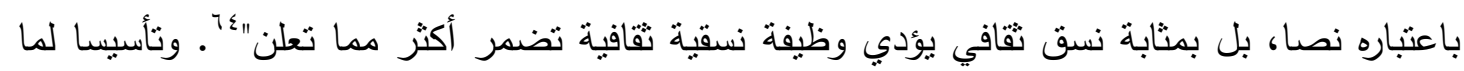
سبق؛ فإن الباحث قد اعتمد في تقسيمه للبحث إلى إطارين أساسيين: نظري (يشمل البعد التظظيري للظاهرة عين البحث)، وتطبيقي (اختار من خلاله عينة بحثية تمثل ظاهرة شعرية تبدو رد فعل لضغط الضط

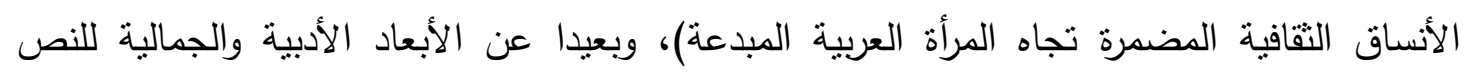

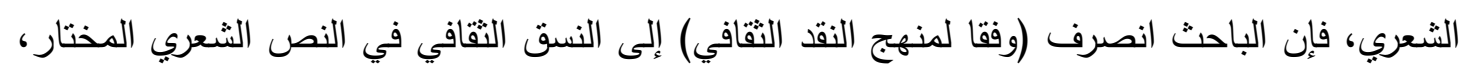
الذي يُضمرِ أكثر مما يعلن؛ وذللك من خلال آلية (مواجهة الذات)، وإنه لتحدٍ (على مستوى النص الشعري) للأنساق الثقافية المضمرة في المجتمعات العربية. أَهدَافُ البَحثبث

يهدف الباحث من بحثث، إلى إثبات عُمقي التحديات التي تعرضت لها المرأة في المجتمعات الإنسانية بعامة، والمجتمعات العربية على وجه الخصوص، من خلال عرض بعض ما استقر في الذائقة العربية؛ عبر مجموعة من الأتساق الثقافية المضمرة، التي أثرت نأثثرا بالغا في حركية وتطور دور دور المرأة الوظيفي في المجتمعات العربية (وخاصة في مضمار الأدب). كما أن البحث يهدف إلى إبراز فعالية إبداع الأدب النسوي المصري والعربي في العصر الحديث.

\section{الإطَارُ النَّطْبِقِيُّ}

حاول الباحث الاهتمام بالبحث في الأنساق الثقافية المضمرة وتحديات الأدب النسوي في المجتمعات

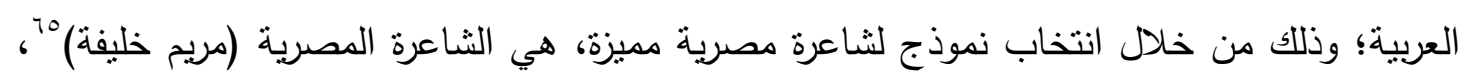
التي استوعبت المنتج التقافي والأدبي المصري والعربي، وأبت أن ثرضى للمرأة العربية التقزبم والتحجيم لأدوارها المنوطة بها في المجتمعات العربية، ووجدت في باحة الثعر؛ الطريق المنلى للتصدي لآثار الأنساق الثقافية المُضدَرَة المغلوطة، في لاوعي المواطن المصري والعربي. ولأن (مريم خليفة) نتنمي 
إلى المستويين الثقافيين، اللذين أثار لهما الباحث آنفا، حال حديثه عن مستويات الكتابة للأدب النسوي؛

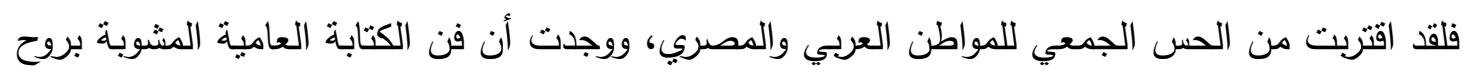

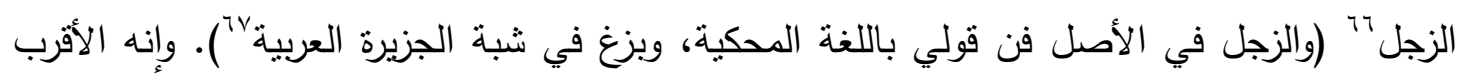

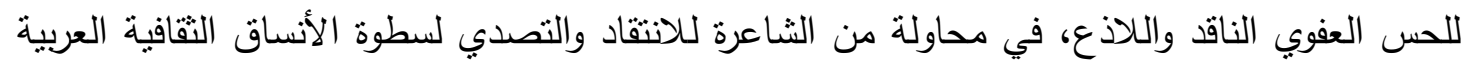

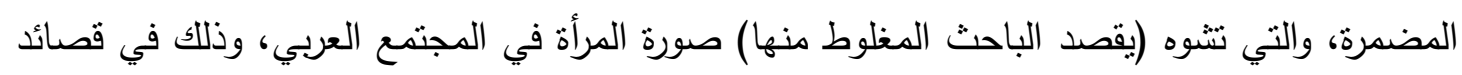

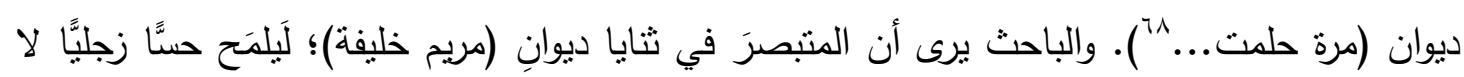

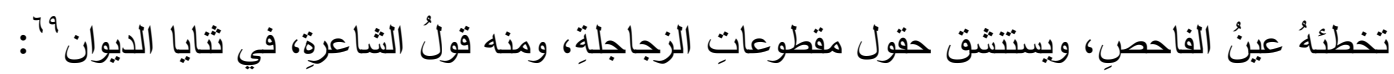

إياك تعانشر ناس قليلة الأصل واخده النداله فـ حقنه زي المصل نقلة الاصل

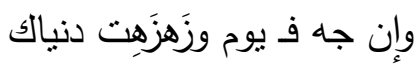

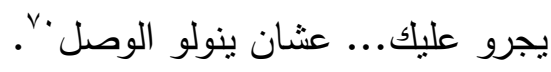

والباحث برى أن (مريم خليفة) قد اختارت الممازجة الواعية، بين العامية المصرية (استجلابا للحس

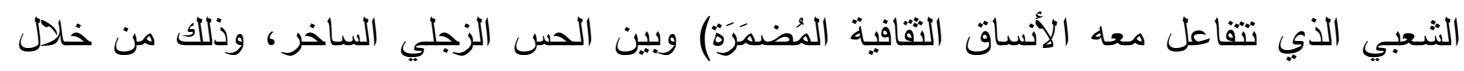

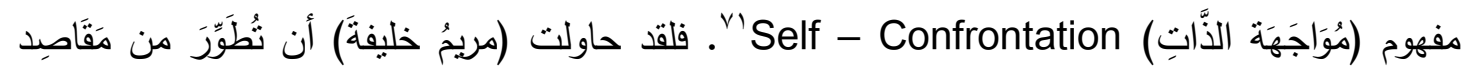

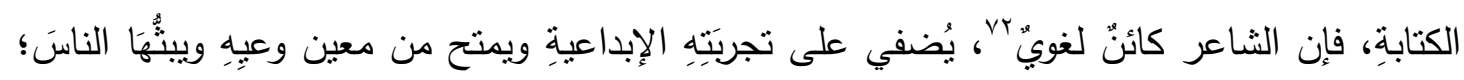

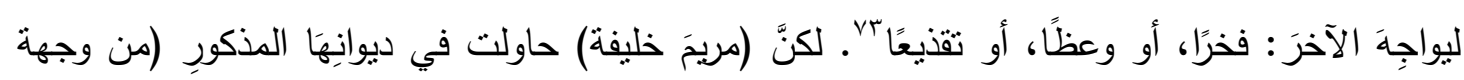

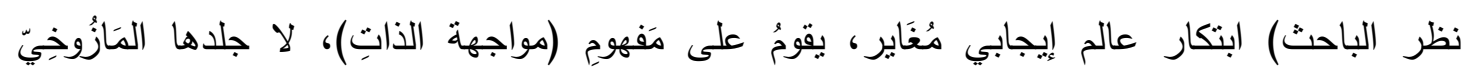
Masochism

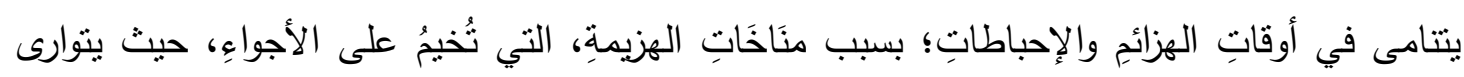

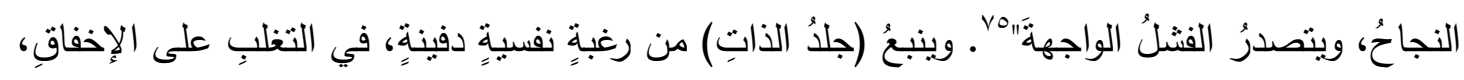

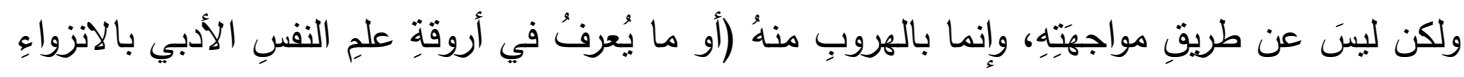

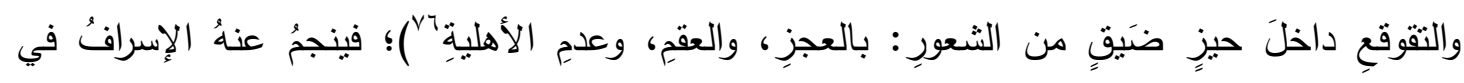

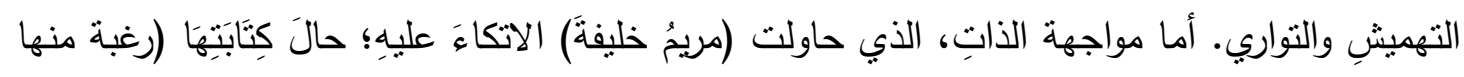

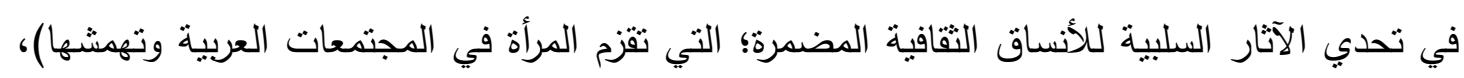

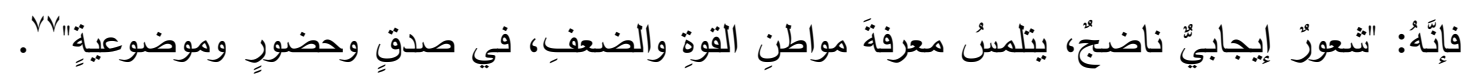

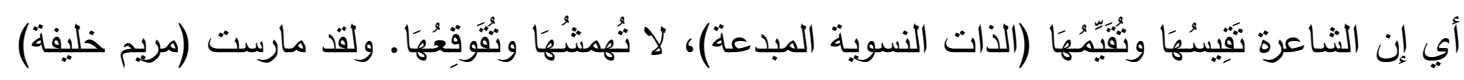

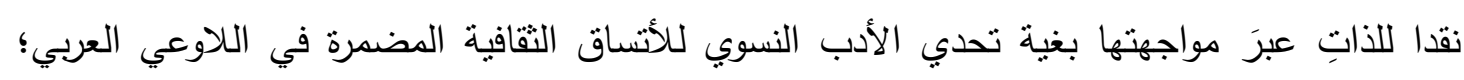

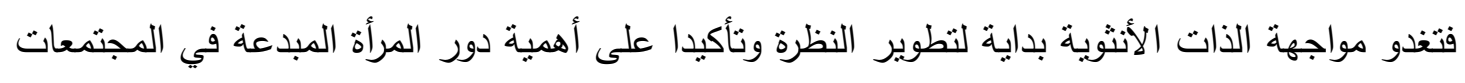
العربية. وذلك وفق حيلٍ فنية عدةٍ، يذكر منها الباحث (وفقا لهنهج النقد الثقافي الذي أثنار إليه آنفار) الآتي بيانه: - n ln

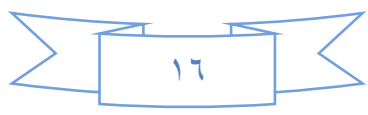




$$
\begin{aligned}
& \text { - - مواجهةُ الذات عبر آلية الاعتراف الذاتي } \\
& \text { البكاء أمام النفس بعد شخوصها ومثولها. ومنه قولها في قصيدة (حالة شجن): } \\
& \text { يمكن ساعات تهرب } \\
& \text { م الدنيا بإرادتك } \\
& \text { تستطعم الوحدة } \\
& \text { وتكون على راحتلك } \\
& \text { تمسك ف غلطاتك } \\
& \text { وتقول لنفسك عيب } \\
& \text { وتقتكر ذكرى } \\
& \text { محضونه بالعفرة } \\
& \text { مركونه ع الدواليب } \\
& \text { وتشب وتجيبها }
\end{aligned}
$$

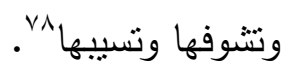

وتقول الثاعرة في إحدى مقطوعاتها النصية، من الديوان المذكور ، ما يؤكد فكرة الاعتراف الذاتي، لكنها هذه المرة تعكس المدلول، محاولة إبدال البسمة بالعبرة الثجية:

$$
\begin{aligned}
& \text { با حضرة جناب المزاج اتعدل } \\
& \text { كفايه سيادتلك كآبه وزعل } \\
& \text { ولو بس تأمر سموك با افندم }
\end{aligned}
$$

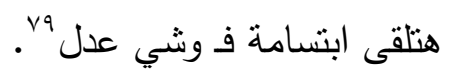

- - وتعود لتتعجب من حال المواجهة، في وصف الذات المعترفة؛ فتقول في قصيدة (تعرف):

$$
\text { تعرف توصف نفسك }
$$

لما بتغرق ف بحور خوفلك

$$
\text { لما بتيجي الضحكة الرايقة من بير جوفلك بوري }
$$

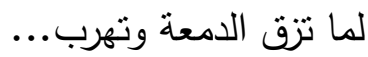

غصبن عنك تملا كفوفلك!".

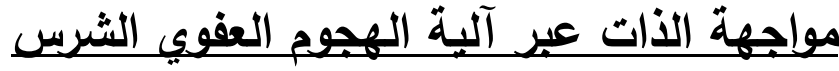

الذي يستتد إلى طاقات النفس الثرهة، والمشغوفة إلى تبيان حقائق الأثياء، بدلا من الاستكانه والخنوع.

$$
\text { ومنه قولها في قصيدة (كُلْه): }
$$

$$
\text { كله خد م التورته حته سقع بالجيلاتي }
$$




$$
\begin{aligned}
& \text { بكتب اللي قلبي حسه } \\
& \text { والقى نفسي بسرعه رصه } \\
& \text { مره أزعل من جنابك } \\
& \text { واتقمص من حتى شمسك 'ي. }
\end{aligned}
$$

ومنه قول (مريم خليفة) في قصيدة (قررت)، والتي تصرخ فيها بأنين المرأة العربية، التي تتحدى الأنساق

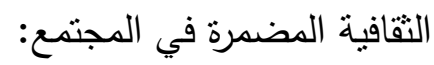
حابسه فـ آه بتثق ضلوعي في الحئ

$$
\text { ورافضه خضوعي }
$$

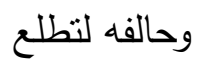

$$
\text { عاوزه تثور قدام الدنيا }
$$

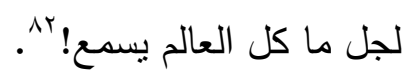

\section{مواجهة الذات عبر آلية الصراع بين الثيع ونقيضه}

ومنه قولها في قصيدة (وبحلفك يا فرح)؛ إذ إن الثاعرة (من وجهة نظر الباحث) قد خلقت صراعا بين

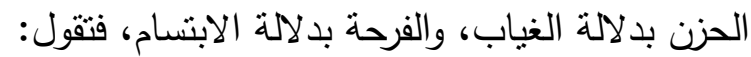

$$
\begin{aligned}
& \text { وبحلفك يا فرح } \\
& \text { ما تطول الغيبة } \\
& \text { ده الحزن مد الطرح } \\
& \text { وعجل الثيبية } \\
& \text { والبسمة متعززة } \\
& \text { وبشدها بالغصب } \\
& \text { وعشانها متترفزة }
\end{aligned}
$$

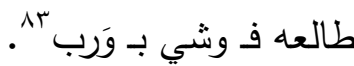

\section{مواجهة الأات عير آلبة الانسلاخ من الأنا الفاعلة إلى الأنا المنفعلة}

وذلك بأن تُقَِّّم الثاعرة ذاتها الواحدة (ظاهريا على الأقل) إلى الأنا الفاعلة، والأنا المنفعلة، ومنه قولها في قصيدة (وِِحَلَّكَكَ بَا فَرح):

والصورة ف المرايات

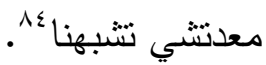


ولقد اعتمدت الثاعرة (في رأي الباحث) على اللعبة الإغريقية القديمة، وهي تبديل الأقنعة (برسونا) أو

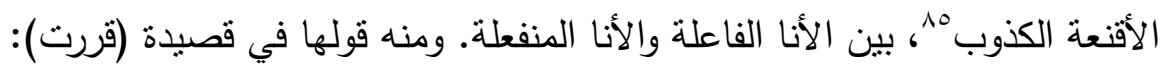

$$
\begin{aligned}
& \text { أصل كتير سايباني الدنيا } \\
& \text { بوش بلاستيك } \\
& \text { وعلى شفايفي بثد الضحكة } \\
& \text { زي الأستكائي }
\end{aligned}
$$

ثم إذ بالثاعرة، تأفل عائدةً إلى فكرة الأقنعة الكذوب؛ إذ إنها تقول في قصيدة (وتجري أيامنا):

$$
\begin{aligned}
& \text { بيرسم ع الوشوش صورة } \\
& \text { لناس تانيه بتشبهينا }
\end{aligned}
$$

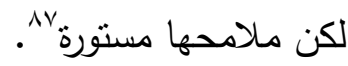

\section{مواجهة الذات عبر آلبة التقنيع والتعنيف}

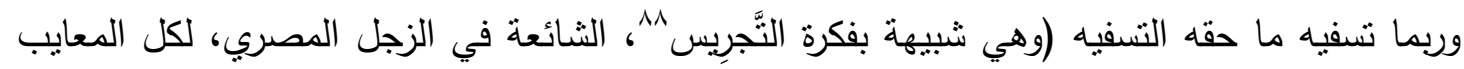

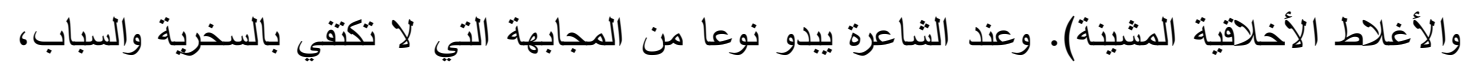

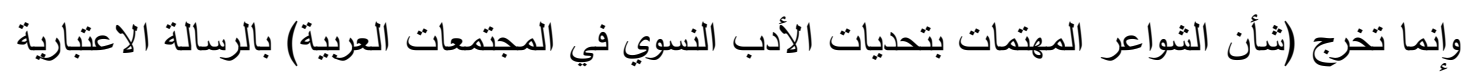

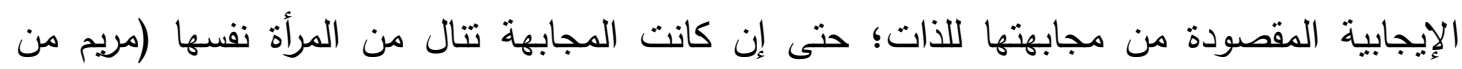

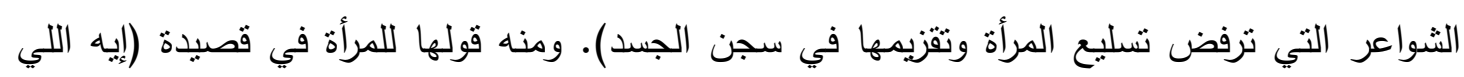

$$
\begin{aligned}
& \text { والبنت هزا وسطها طول النهار } \\
& \text { بيقولوا ده ميثاق الثرف } \\
& \text { خليتوا حالنا بالبلا } \\
& \text { كل النساء اتقدمت } \\
& \text { إلا نسائنا بجهذكم }
\end{aligned}
$$

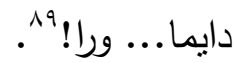




\section{مواجهة الأات عبر آلبة الاستتاد إلى الريز المُعَمَّى}

وهي حيلة صارت المفردة الثعرية (وفقها) تعبر مباشرة عما يراود صائغها، لكن الآلية الدذكورة (بقليل

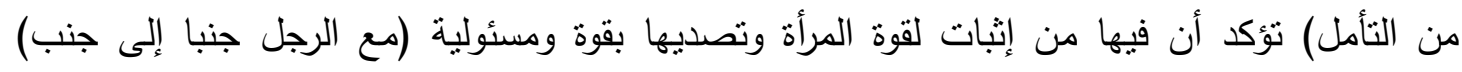

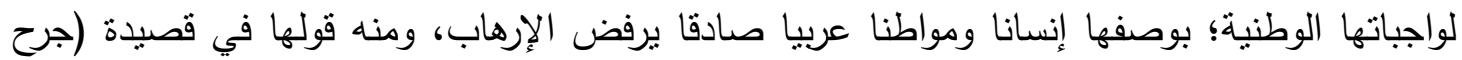
وطن):

$$
\begin{aligned}
& \text { والغراب الاسود ف سينا } \\
& \text { إحنا قادرين نعدمه } \\
& \text { مش هيقدر يوم علينا }
\end{aligned}
$$

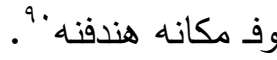

مواجهة الذات عبر آلية التحريض هن

وإن هذه الآلية لَتَفَعَل (من وجهة نظر الباحث) قوى الذات الأنثوية (المستتفرة أصلا) وتحفزها إلى مزيد

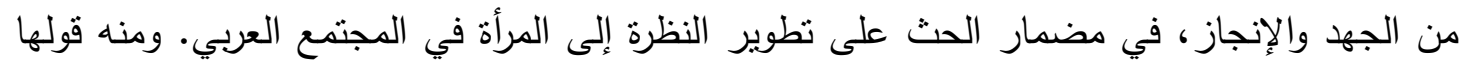

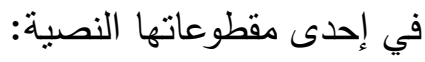

$$
\begin{aligned}
& \text { يا صاحب الحرف } \\
& \text { إوعى ينحني قلمك } \\
& \text { فضفض على سطورك } \\
& \text { خلينا جمهورك } \\
& \text { خَضَّرلنَا حَرفَكَ } \\
& \text { واعزف لنا ألمك } \\
& \text { إعلن لنا... حضورك" ل. }
\end{aligned}
$$

\section{مواجهة الذات عير آلية التجريد وإقصاء التجنيس}

رأى الباحث أن الآلية المشار إليها لها عمق في ميدان تحديات الأدب النسوي في المجتمعات العربية؛

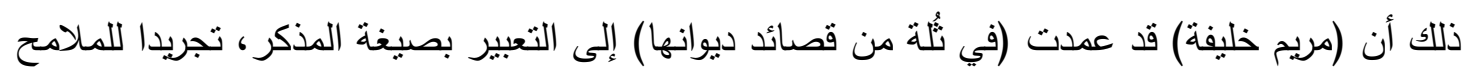

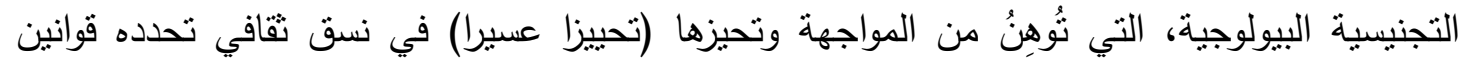


البيولوجيا، لا رحابة الإنسانية. ومنه قولها في من قصيدة (منيش سنَّبّد)، والباحث برى أنها عَبَرَت بصيغة التجريد الدذكرة عن ذاتها، التي تصطرع بعنف:

$$
\text { وأنا ومش مغرور }
$$

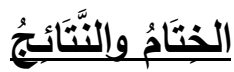

وإن الباحث ليهدف من بحثه، إلى تأكيد النتائج الآتي بيانها:

1- أن المجتمعات العربية لم تكن (في يوم من الأيام) عاقرا عن استيلاد نساء مبدعات؛ يقدمن

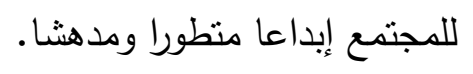

r- أن الكتابة النسوية العربية في العصر الحديث، هي رؤية عميقة مُوَسََِّةُ لواقع وآفاق المرأة

$$
\text { العربية في العصر الحديث. }
$$

r- إبراز دور المرأة العربية في المشاركة الجادة والعميقة، في تطوير الأنساق الثقافية المضمرة،

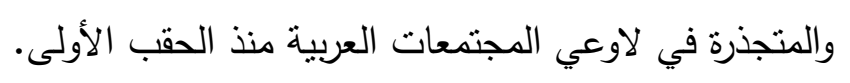

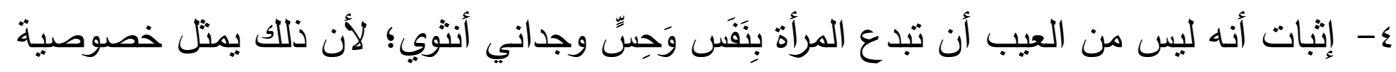

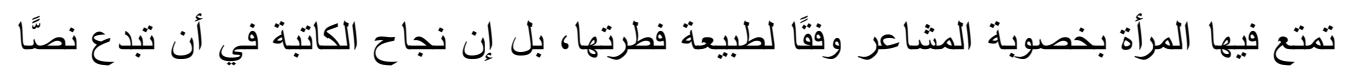
بمذاق أنثوي فياض بالدالات والتجارب الإنسانية؛ يضفي (بالضرورة) على تجربتها الأدبية، صدقًا يمس القلوب والعقول معًا.

ه- التأكيد على أن الأدب النسوي (في جوهره) مرتبط بالحركة النسوية، وسعيها الحثيث، لتحصيل

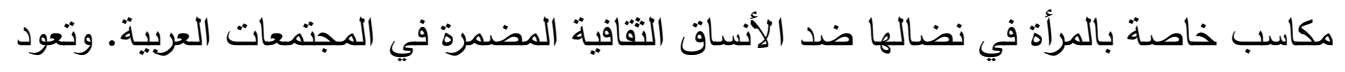

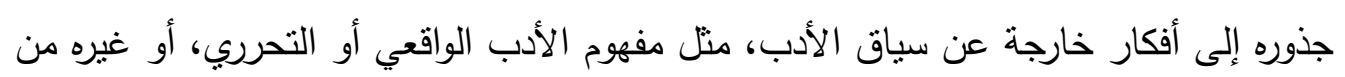

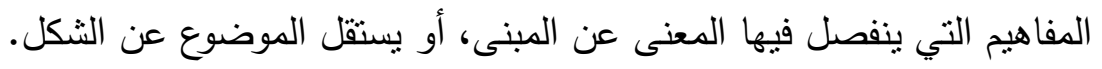

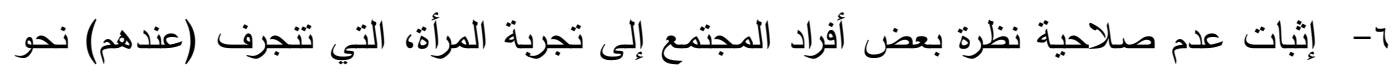

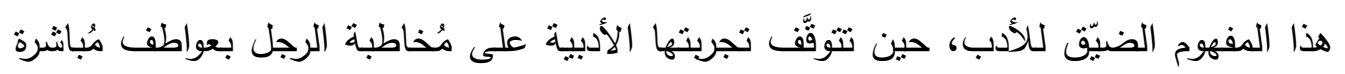

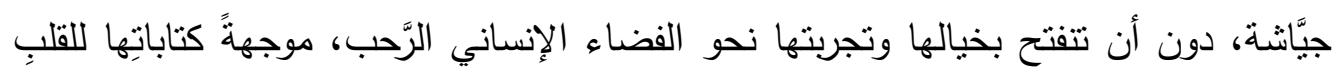

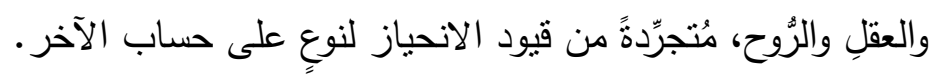

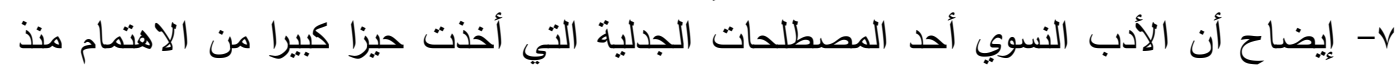

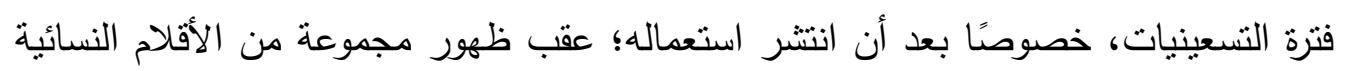
الواعدة في مختلف الدول العربية.

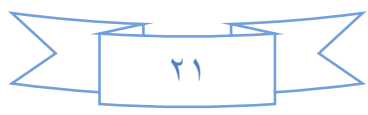


^- استجلاء خصوصية تجربة الأدب النسوي؛ إذ إن التاريخ الإنساني (عقب حقبه المختلفة) قد غَيَّبَ (نوعا ما) صورة المرأة الأديبة، ولم يضعها موضعها اللائق بها. 9- دراسة نموذج تطبيقي من نماذج الأدب النسوي (يتمثل في ديوان: "مرة حلمت"، للشاعرة المصرية: مريم خليفة)؛ وفق منهج (القراءة الثقافية)، الذي ينأى عن ضوابط وقوانين المناهج التقليدية والفنية، في تتاول الدرس الثعري، ما يتسق مع مفاهيم الأنساق التقافية المضمرة، الذي يعتمد عليه الإطار النظري للبحث. • ا- إثبات أن القضايا الإنسانية واحدة، يتجاوب وينفعل بها الجنسان، وتظل لدى طرفي المعادلة ثلة من الأثياء الخاصة، فبينما يبدو الرجل جسورا في الكثف عن ملامح عاطفته، نجد أن الاسترسال العاطفي لدى المرأة في المجتمعات العربية، يأخذ صيغًا غير مباشرة تغلفها العفة ويزينها الخجل، لكنهما (في الوقت نفسه) يكتبان معًا (وبنفس القدر من الموهبة) عن حاجات الإنسان، وفضاءات طموحاته المتدفقة. 1ا- إلقاء الضوء البؤري على الخطاب النقافي الثعري النسوي في العصر الحديث، وما يقدمه من أطروحات فكرية وثقافية ترنو إلى أفق ثقافي جديد. 


\section{حواشثي البحث}

1- وفي ذلك يقول الباحثون: "مازال المجتمع العربي بعامة والمصري -إلى حدٍ ما- ينظر إلى

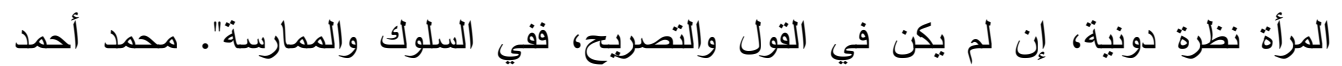

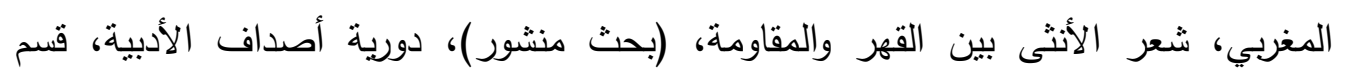

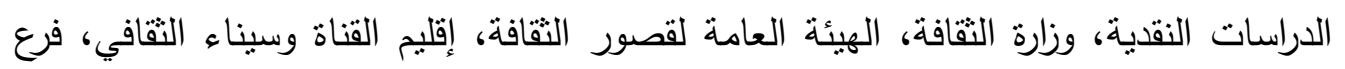

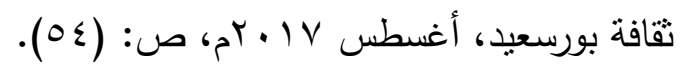

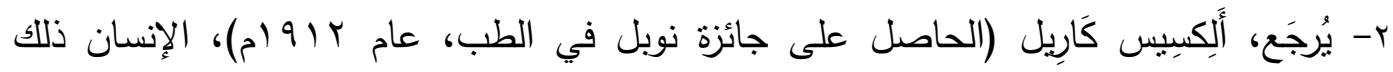

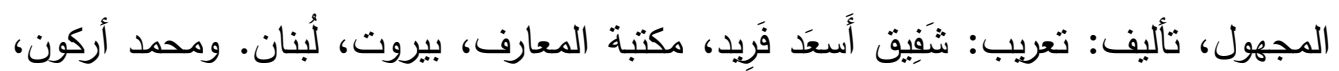

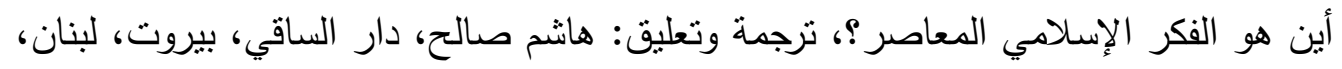

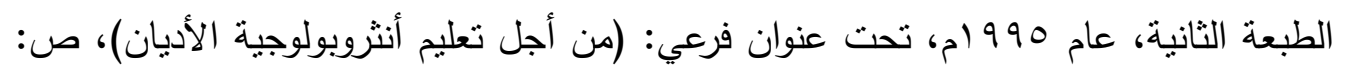

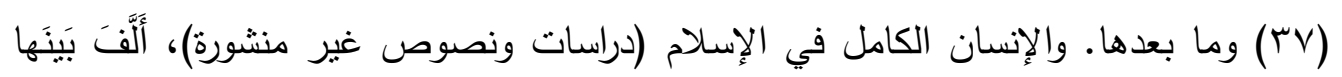

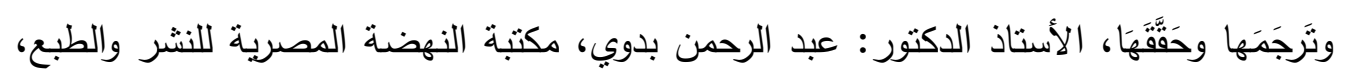

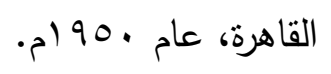

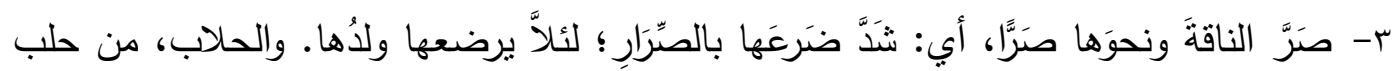

$$
\text { الناقة ونحوه. }
$$

ع- عبر مراسم الحمل والولادة. يُرجع، الأنثى والإنسان، د. مفيد يحيى الكاثشف، دار ومطابع الفكر

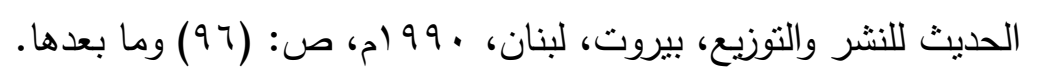

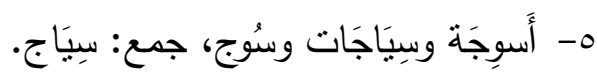

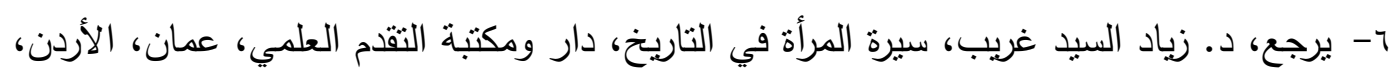

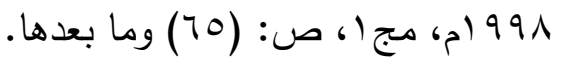

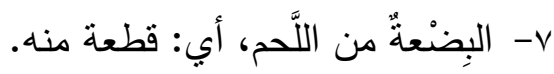

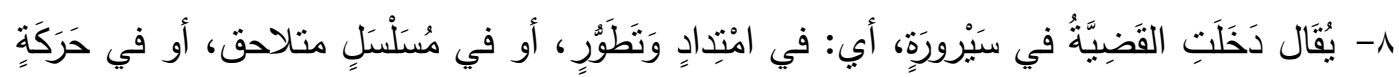

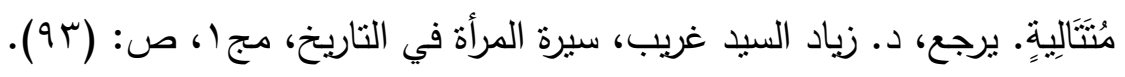

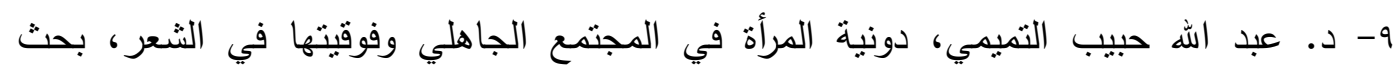

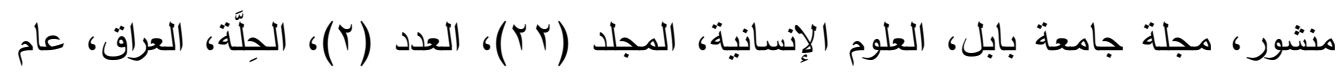

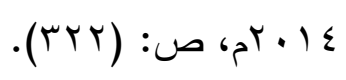

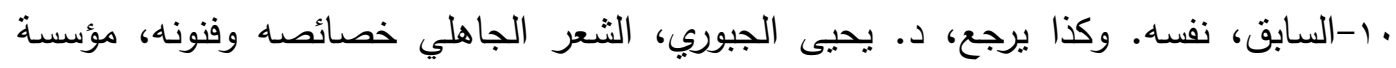

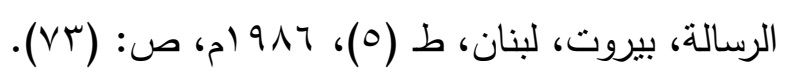

1ا- د. عبد اله حبيب التميمي، دونية المرأة في المجتمع الجاهلي وفوقيتها في الثعر، ص: 
كا - يرجع، د. زياد السيد غريب، سيرة المرأة في التاريخ، مج ا، ص: (ع V).

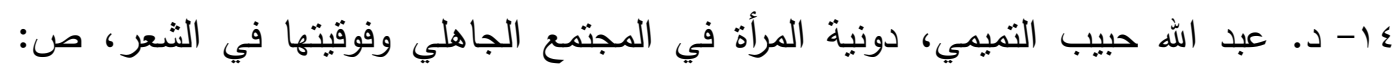

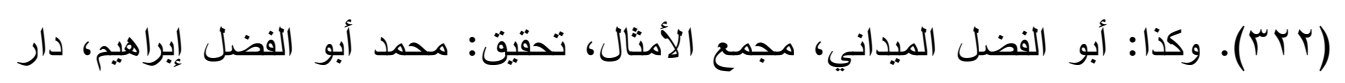

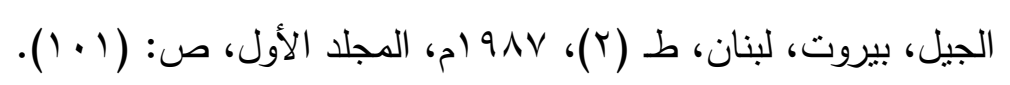

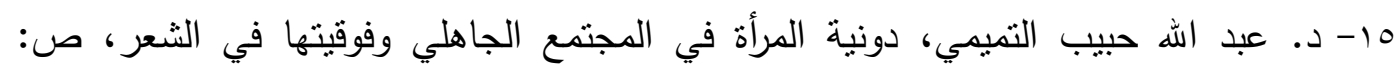

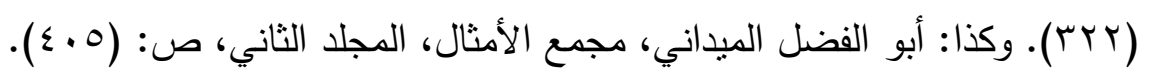

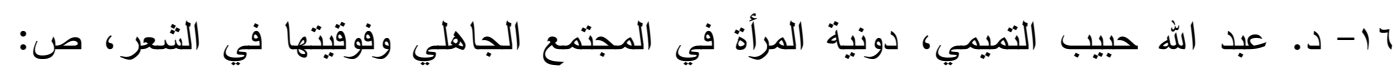

(Trt)

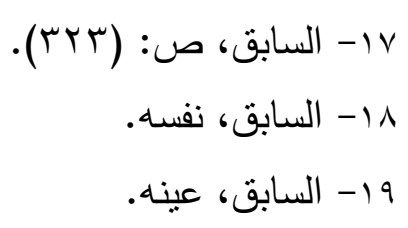

•r- القرآن الكريم، سورة النساء، الآية رقم: (9 (1).

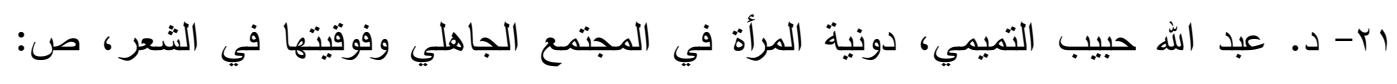

(rtr)

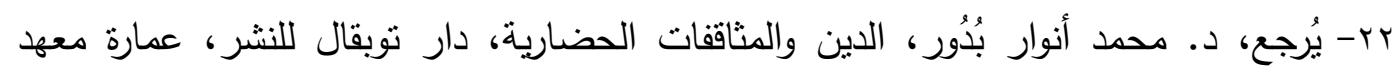

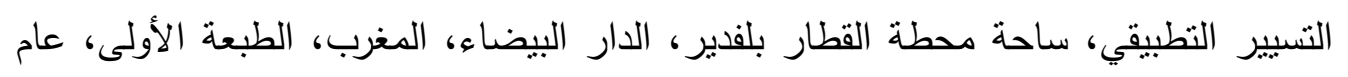

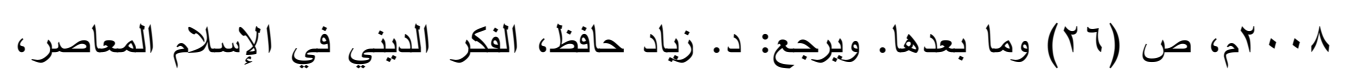

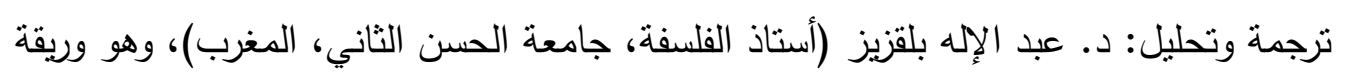

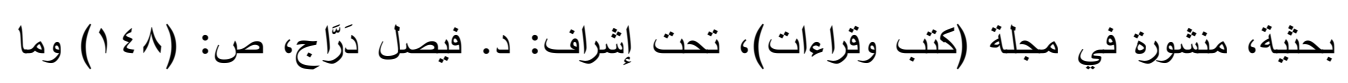
بعدها.

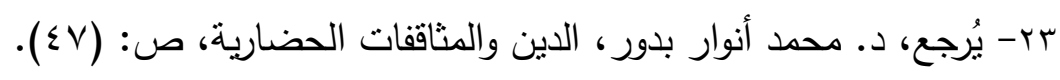

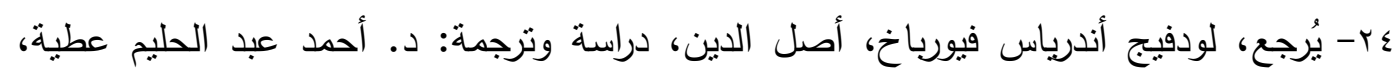

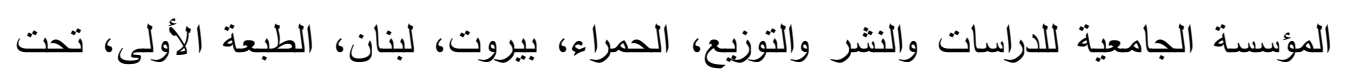

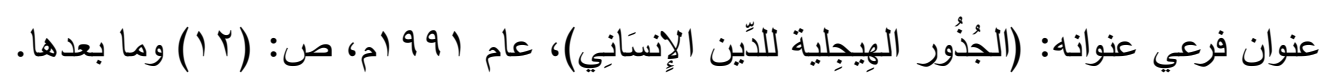

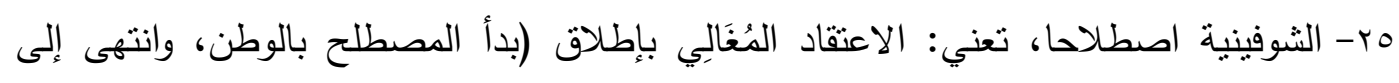

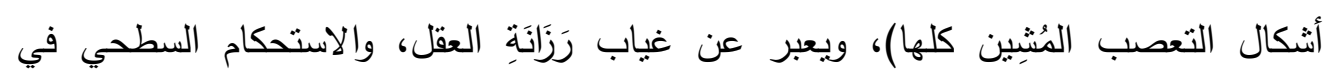

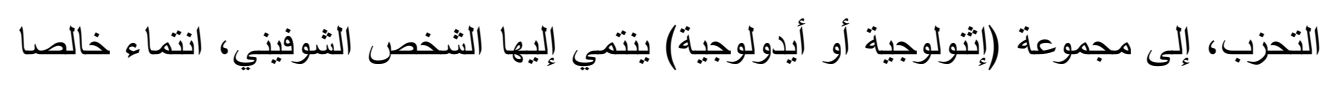

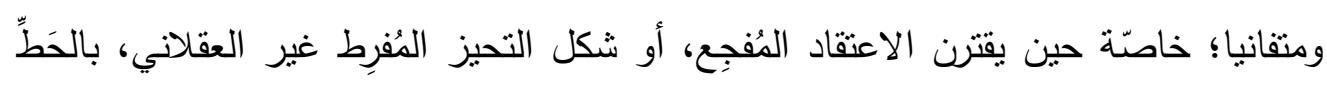

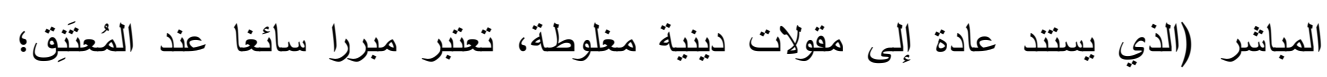

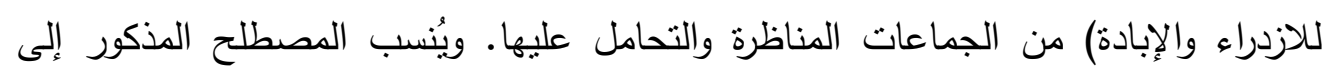

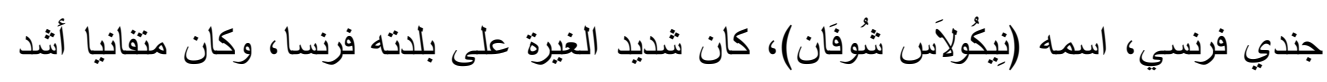

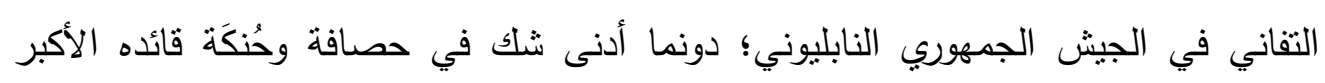

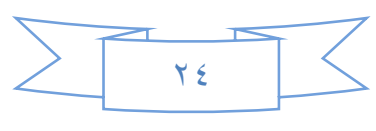


(نابليون). فجرت العادة على الإثشارة إلى التفاني الأعمى خاصة الجندي المتحمس والمتزمت (في عَنجَهِيَّة) برأيه، في أية قضية، أنه (شُوفِينِي). ولقد أشناع التسمية في المجتمع الأوروبي، مسرحية هزلية للأخوين كونيارد، بعنوان: (الثريط ذي الألوان الثلاثة)، وفيها دور (نيكولاس النهاع شوفان) الجندي المعذب بالوطنية المفرطة، حد التجهم الكاريكاتوري. والمصطلح (إجمالا) يؤشر إلى معنى التعصب المأفون الضرير • والمقصود في سياق البحث؛ التعصب ضد المرأة؛ بوصفها جنسا دنيئا، قليل الثأن. يرجع، د. مصطفى رشيد أبو النجا، مصطلحات عالمية،

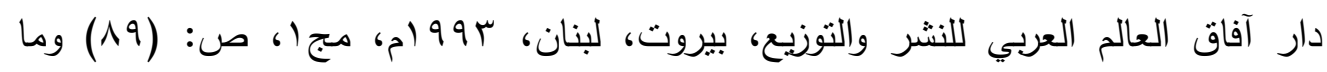
بعدها.

بr- يُرجع، سيجموند فرويد، الحب والحرب والحضارة والموت، دراسة وترجمة: د. عبد المنعم

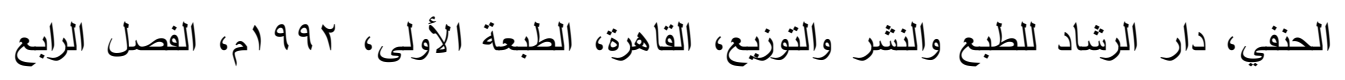

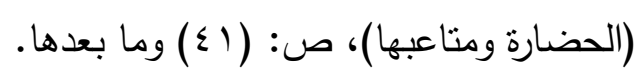

Vץ- الزَّرَافَة: الجماعة من الناس، وجاءوا زَرافات وَوحدَانا (تعبير عربي مَسكُوك)، بمعنى: جاعوا

$$
\text { بأعداد غفيرة. }
$$

^ץ- د. طالب حَمَّاد أبو شعر، الأحاديث الموضوعة في المرأة وخطرها على الإسلام، دار الأمين

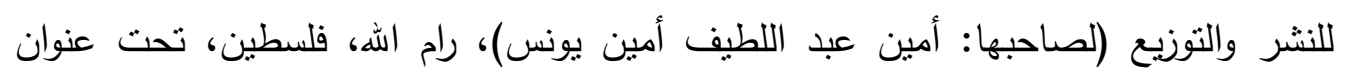

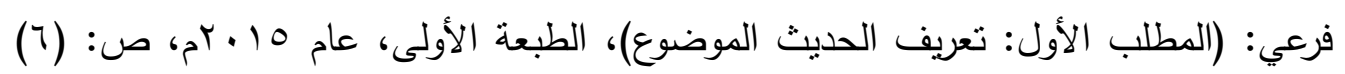
وما بعدها. 9 ૧- السابق، نفسه. • ז- أبو الحسين أحمد بن فارس بن زكريا القزويني الرازي (ت 90بهـ)، معجم مقاييس اللغة،

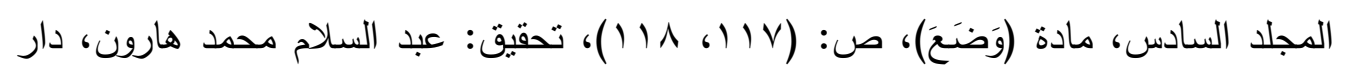

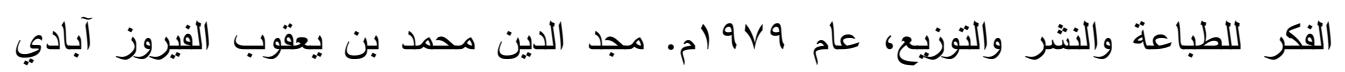

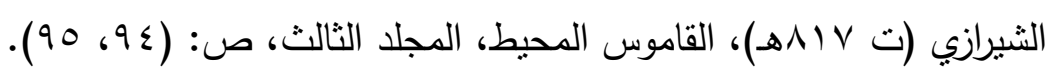
اب- د. سلام عبد القدوس، الحديث الموضوع وخطورته في المجتمع الإنساني، مكتبة دار الوليد

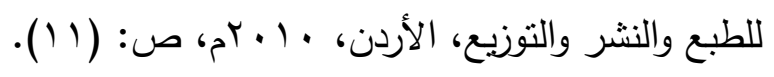

$$
\begin{aligned}
& \text { r r- يرجع، السابق، ص: (r ( ). } \\
& \text { rr- يرجع، السابق، نفسـ. } \\
& \text { ـז- يرجع، السابق، ص: (ع (1). } \\
& \text { هr- يرجع، السابق، ص: (1) (1). }
\end{aligned}
$$

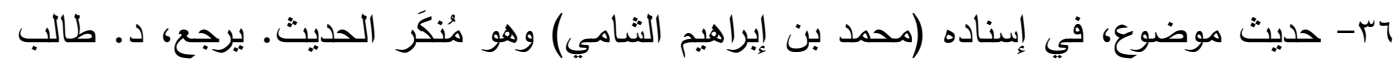

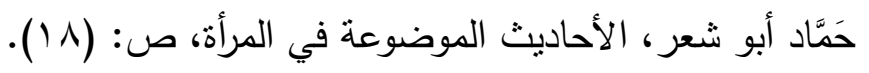

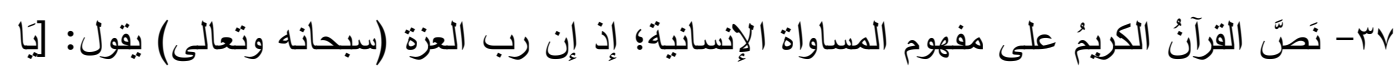

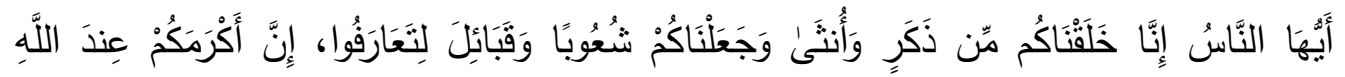




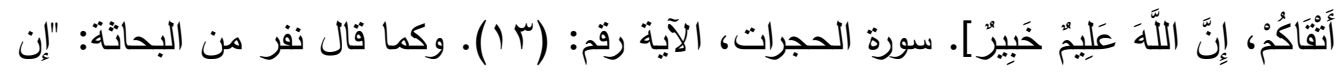

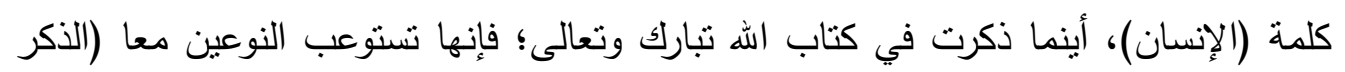

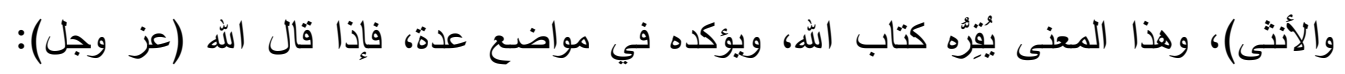

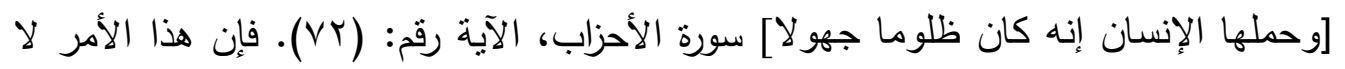

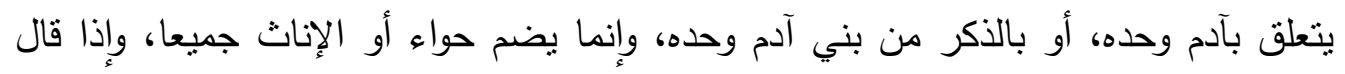

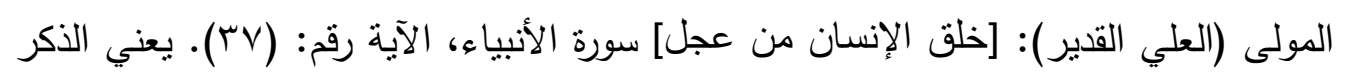

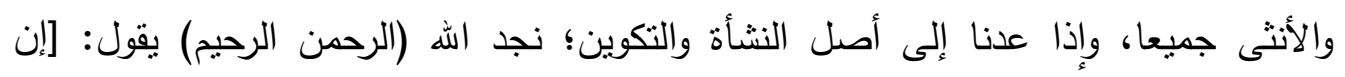

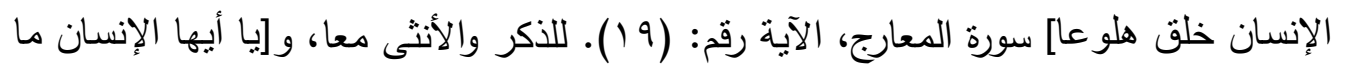

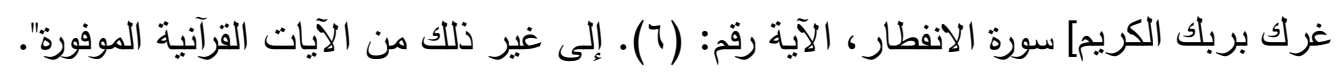

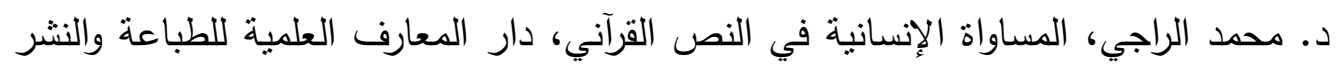

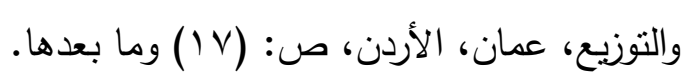

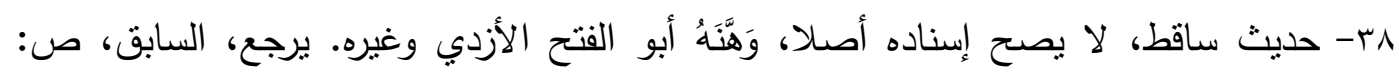

$$
\text { 9 9- حديث موضوع ومنكر • يرجع، السابق، نفسه. }
$$

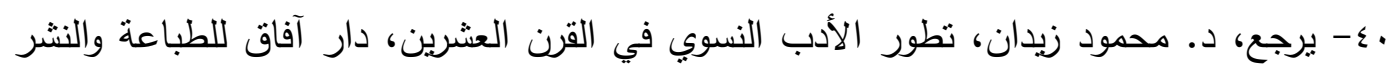

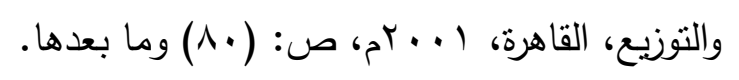

اء- د. أيمن تعيلب، الإبداع بين سلطة الخيال وسطوة الواقع، بحث منشور، كتاب أبحاب أبحاث المؤتمر

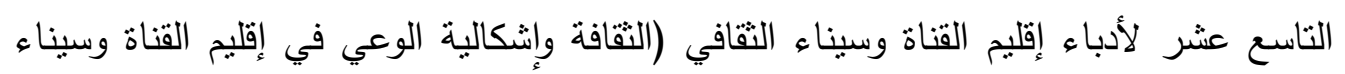

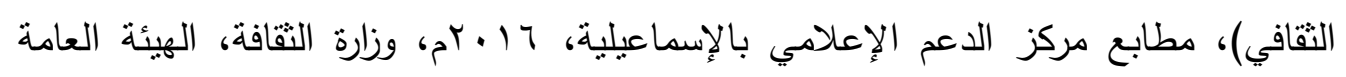

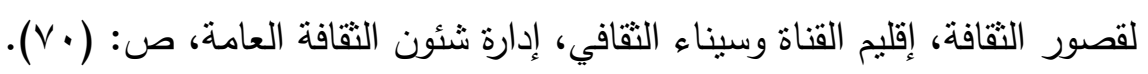

$$
\begin{aligned}
& \text { rع- السابق، نفسه. }
\end{aligned}
$$

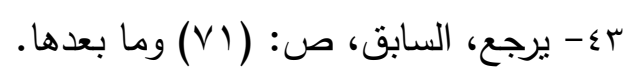

؟ ؟- د. جميل حمداوي، نحو نظرية أدبية ونقدية جديدة (نظرية الأنساق المتعددة)، كتاب الألوكة،

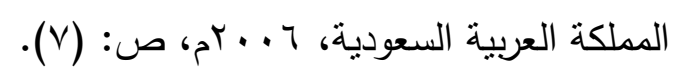

0ـ- السابق، نفسه.

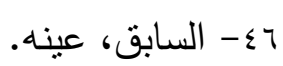

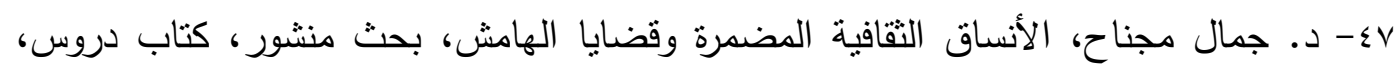

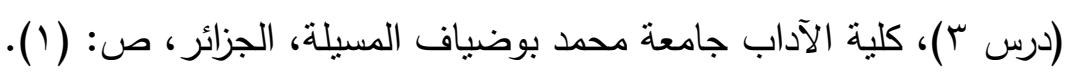

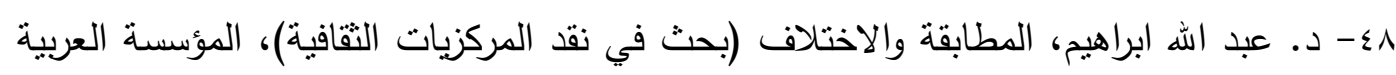

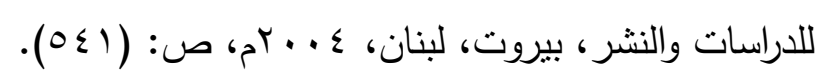

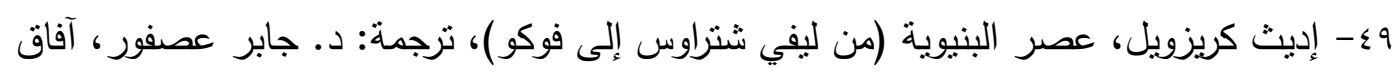

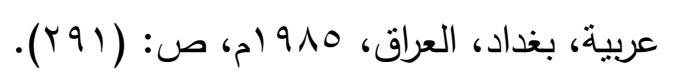


•- د. نعمان بوقرة، المصطلحات الأساسية في لسانيات النص وتحليل الخطاب (دراسة معجمية)،

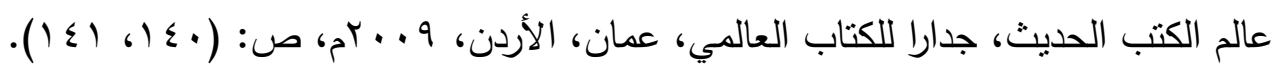

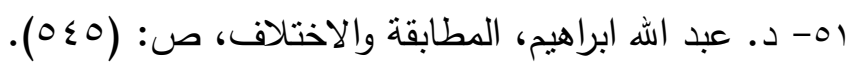
ro- أحمد يوسف، القراءة النسقية (سلطة البنية ووهم المحايثة)، منشورات الاختلاف، الجزائر،

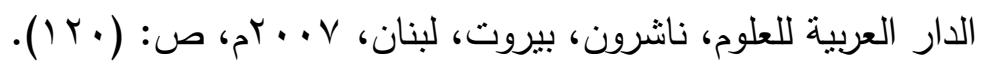

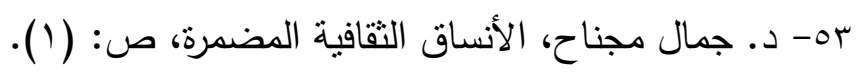

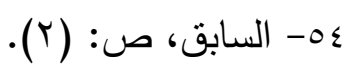

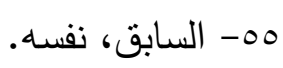

1ه- د. عمار إبراهيم الياسري، الأنساق المضمرة في بنية النص الثعري (دراسة في نصوص الثهاء الثاعر الدكتور عمار المسعودي)، مجلة (صحيفة المثقف)، بغداد، العراق، العدد رقم:

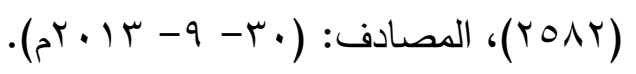

$$
\begin{aligned}
& \text { 次 }
\end{aligned}
$$

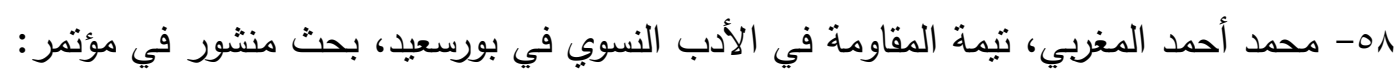
(فلسفة المقاومة في الأدب البورسعيدي)، مؤتمر بورسعيد الأدبي لليوم الواحد، الدورة التاسعة، الادئ 10 ثقافة بورسعيد، ص: (r^). 9ه- ومن جملة قول الباحثين حول المصطلح: "يعد مصطلح الأدب النسوي من المصطلحات الحديثة التي ظهرت في السياق التقافي المعاصر وقام حوله جدال، واعتراه نوع من اللبس والغموض، حتى اختلطت مشاربه، واختلفت حوله آراء النقاد والمهتمين بشؤون الأدب". د. د.

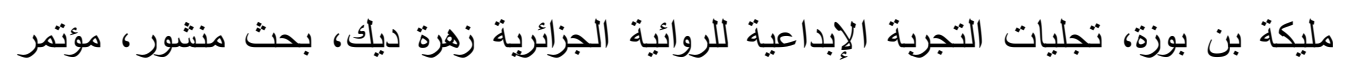
(المرأة في الخطاب الأدبي الإعلامي والثقافي)، وقائع المؤتمر الأدبي الدولي الثالث، كلية

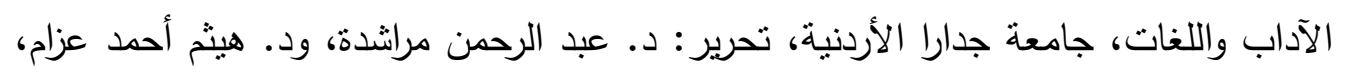
دار الكتاب الثقافي، إربد، الأردن، ص: (VYV). ومن ذلك (أيضا)، اختلاف النقاد والأدباء الآتية أسماؤهم حول مصطلح الأدب النسوي: "فلقد تحدث الدكتورة (ثريا العريض) الأديبة السعودية قائلة باستفاضة إنه ليس ثمة اتفاق بثأن مفهوم (الأدب النسائي)، كما أن الكاتبة

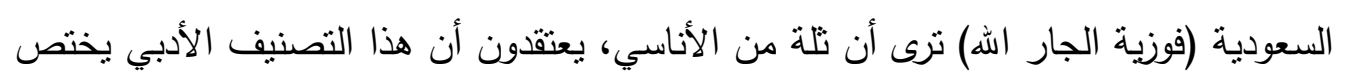

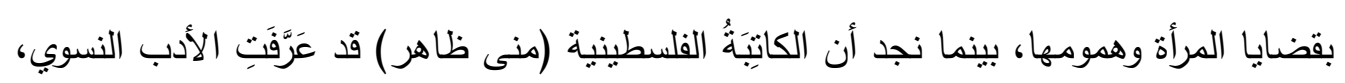

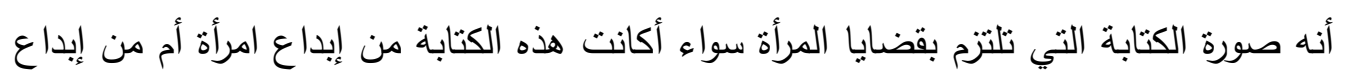
رجل. إن عدم المساواة بين الجنسين "الذكر والأنثى" ليست نتيجة حتمية للاختلاف البيولوجي،

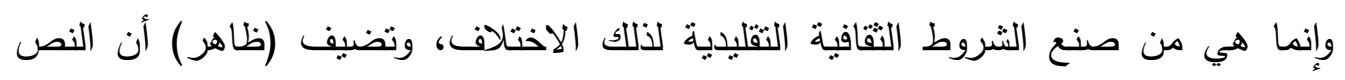
النسوي هو الذي يأخذ المرأة باعتبارها فاعلا، حيث يولد النص مهوما بالأنثوي المسكوت الأني

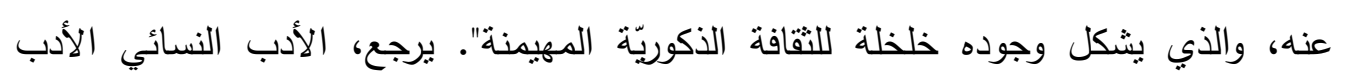

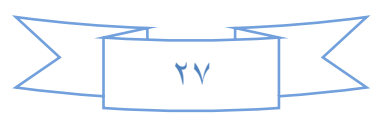




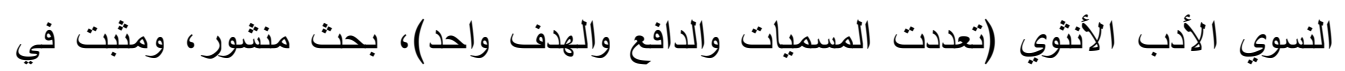

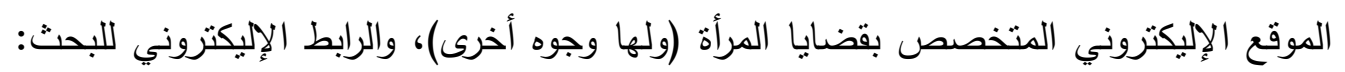

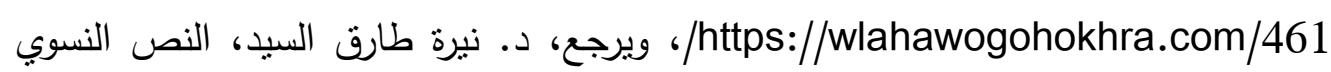

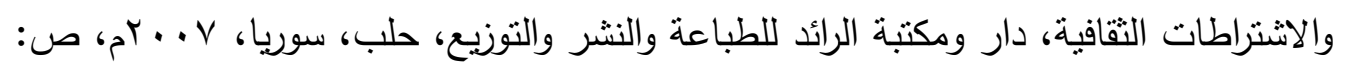

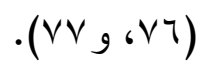

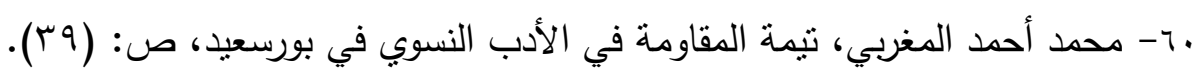

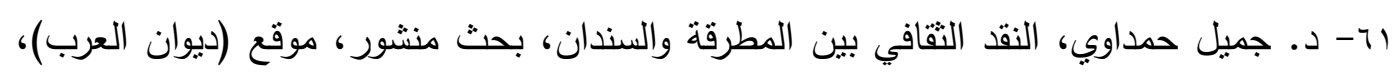

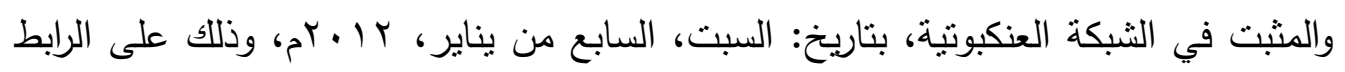
الإليكتروني الآتي: https://www.diwanalarab.com. זٓ- السابق، نفسه. זٓ- السابق، عينه.

ء ז- السابق، ذاته. ويرجع، د. مازن داوود سالم الربيعي، ديوان نجاح العرسان (فرصة للتلج) قراءة

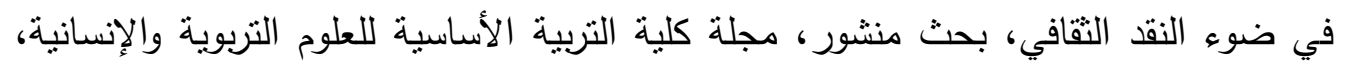

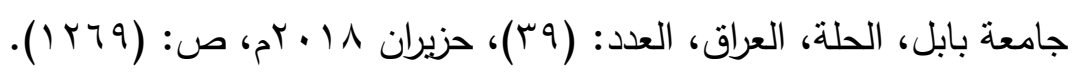

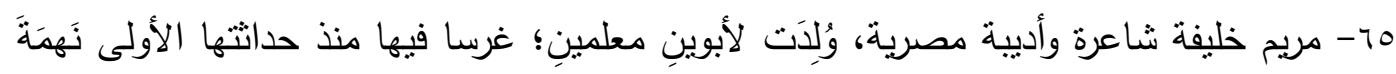

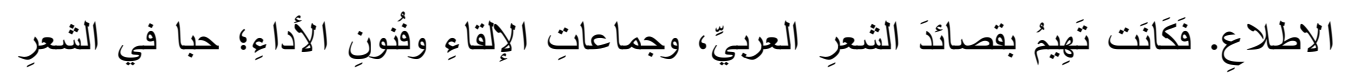

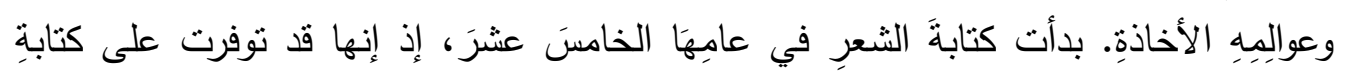

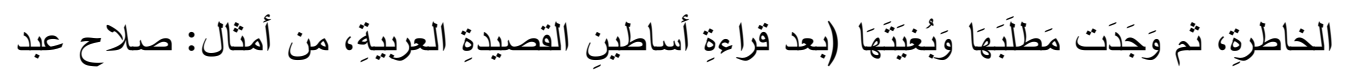

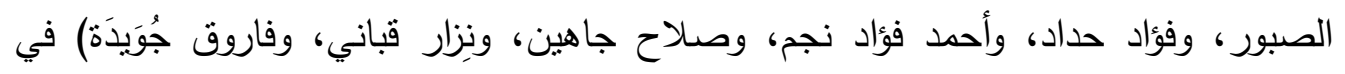

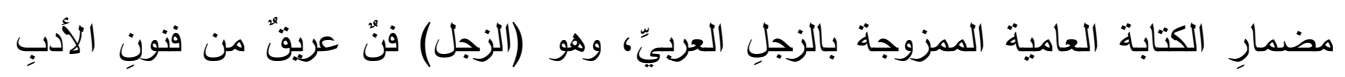

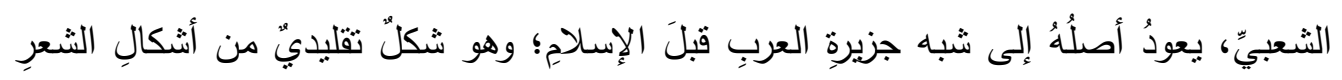

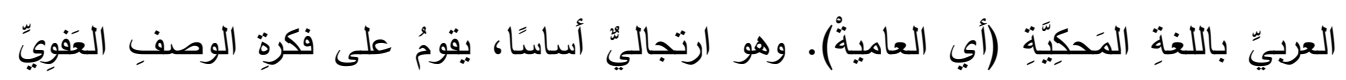

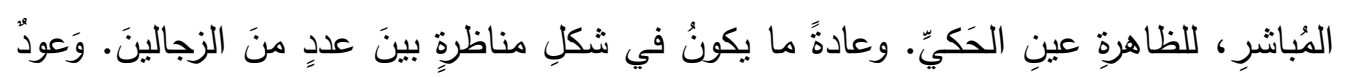

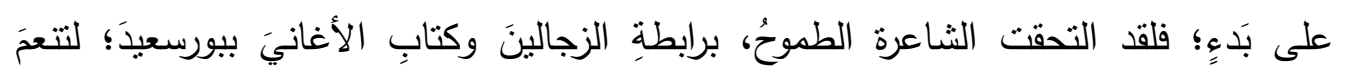

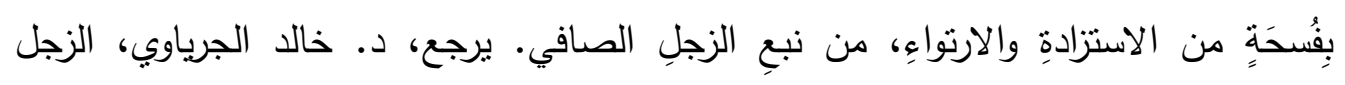

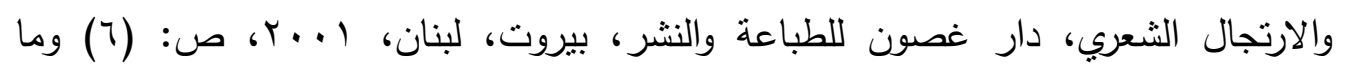

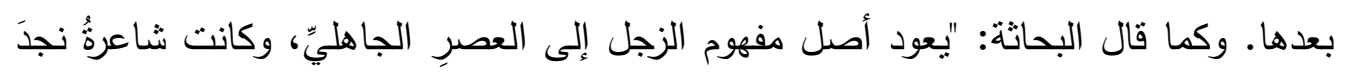

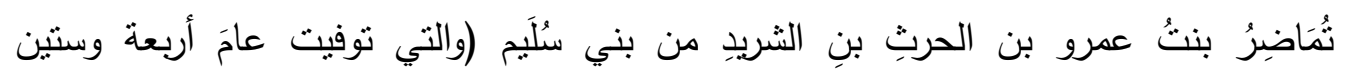

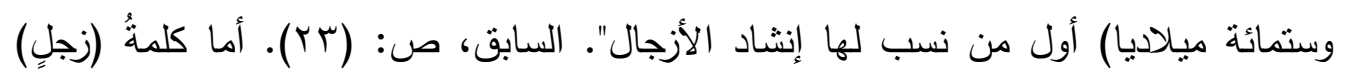

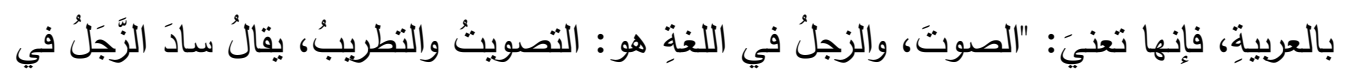

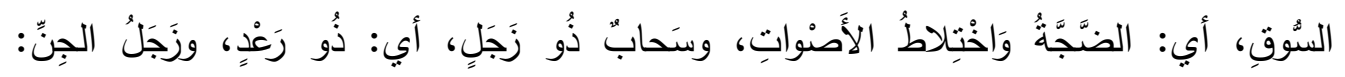

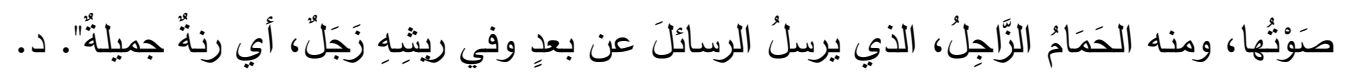

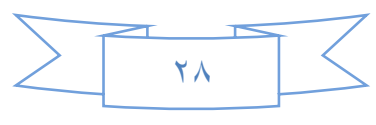


محمد عبد الحكيم، الزجل العربي وفنون القول، دار ومكتبة التراث العربي، بيروت، لبنان،

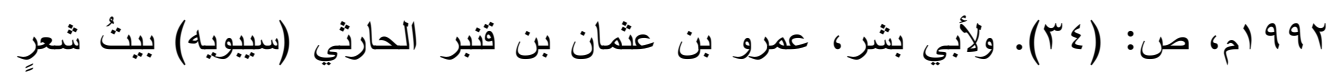

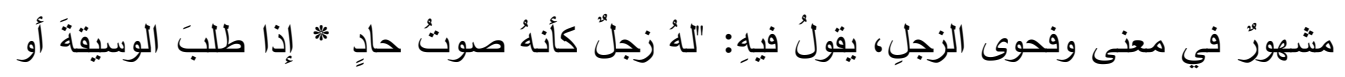

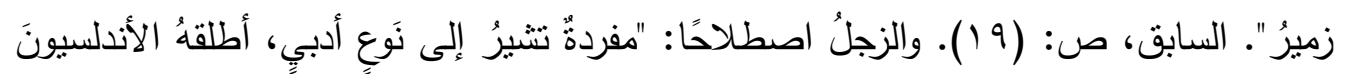

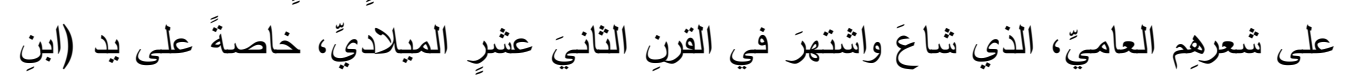

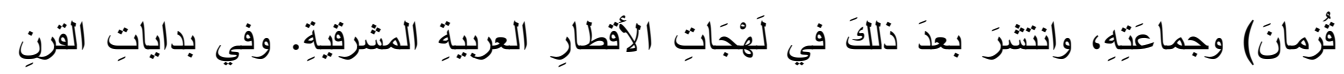

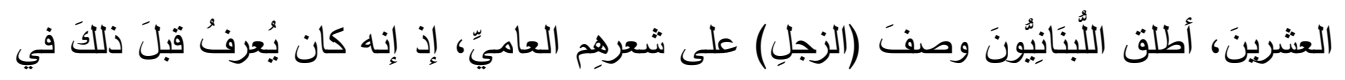

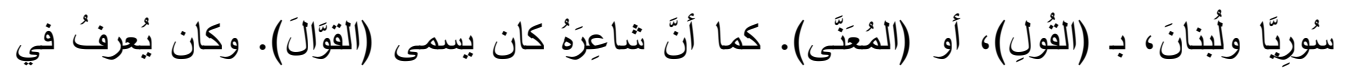

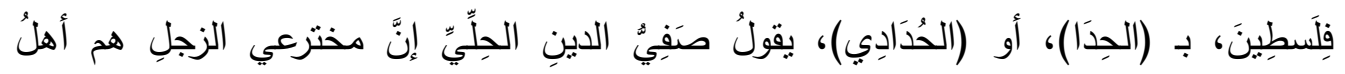

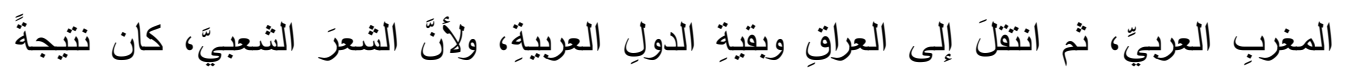

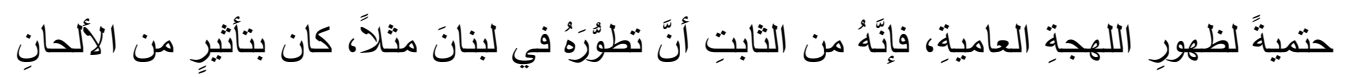

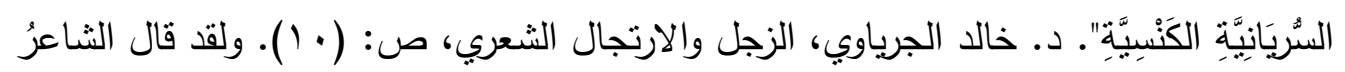

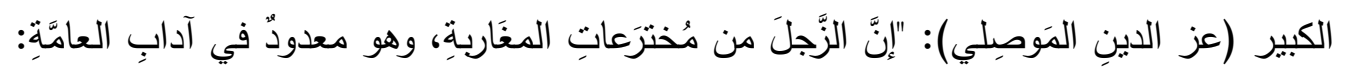

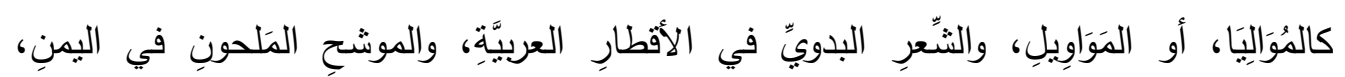

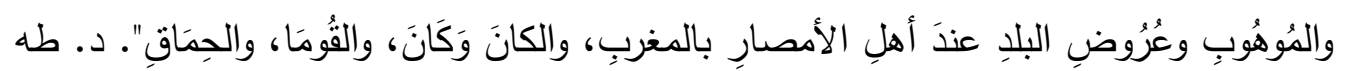

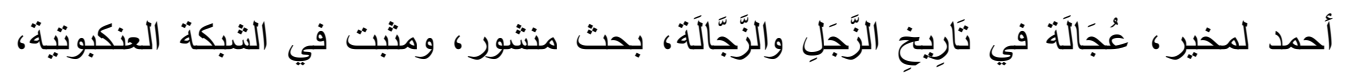

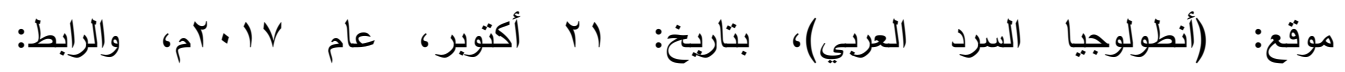

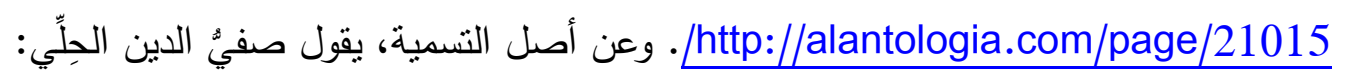

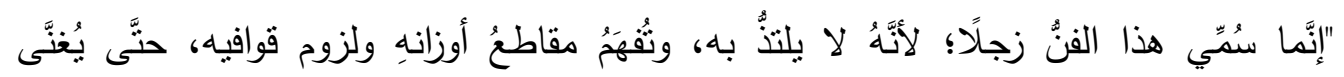

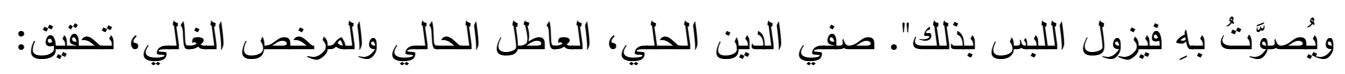

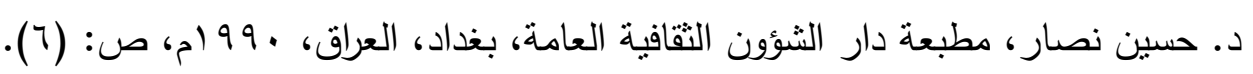

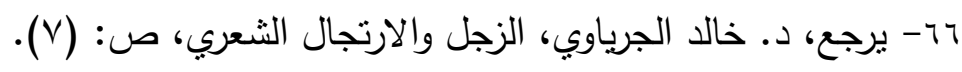

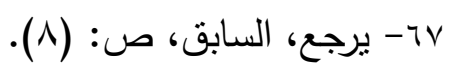

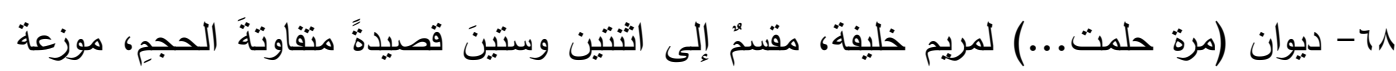

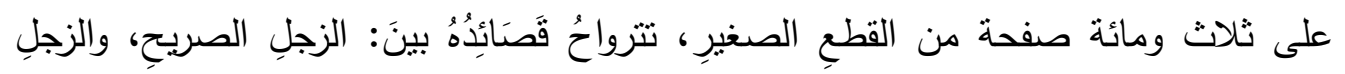

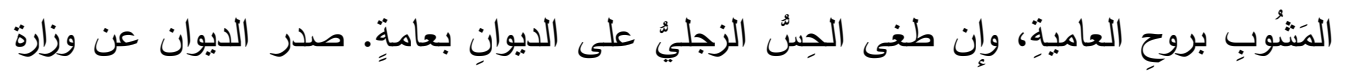

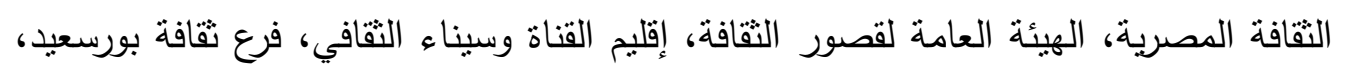
عام 17 . بام.

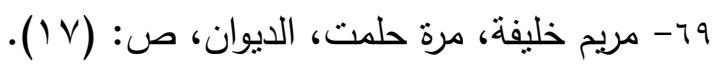

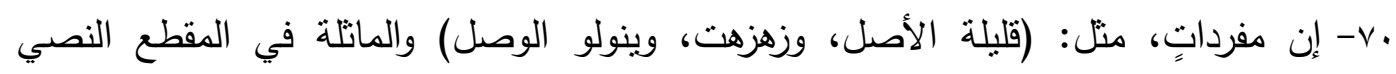

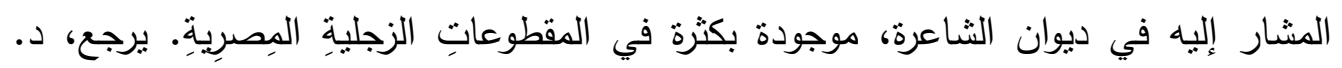


محمد عبد الحكيم، الزجل العربي وفنون القول، ص: (VA) وما بعدها. وتقول الثاعرةٌ أبضًا،

$$
\text { في الديوان المذكور، قصيدةِ (دنيا عجب): }
$$

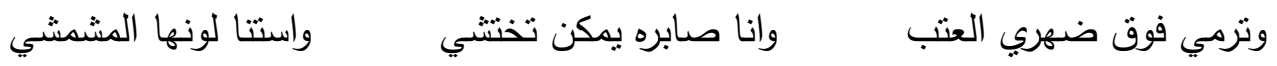

$$
\text { يمكن سوادها يتحجب!. السابق، ص: (ب (Y). }
$$

الي- يرجع، د. عبد الرحمن حبيب، الأدب الحديث من منظور نفسي معاصر، دار ومكتبة علوم

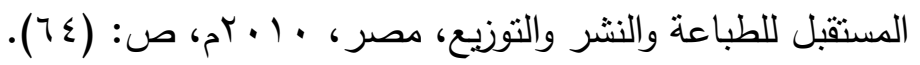

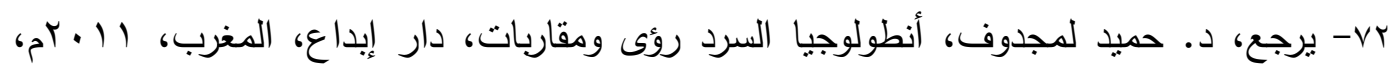

$$
\text { ص: (ع (0) وما بعدها. }
$$

r برجع، د. سميح السيد، التجربة الشعرية وسلطة التخييل، دار طلائع الإبداع للطباعة والنشر وهر

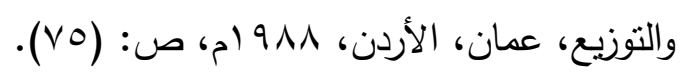

ع V- يرجع، د. نعيم عبد الواحد، الاضطراب النفسي وأثره في مضامين الإبداع، دار ومكتبة الفكر

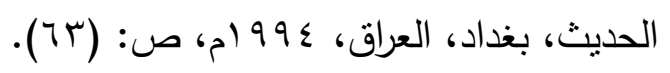

(السابق، ص: (10) (10)

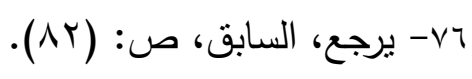

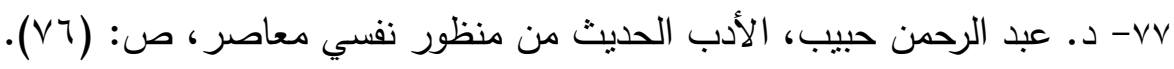

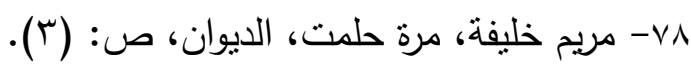

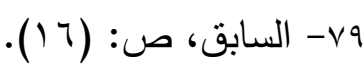

.

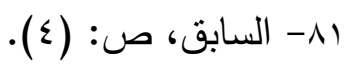

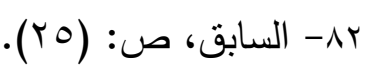

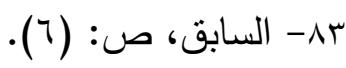

ـ ـ- السابق، نفسه.

ه-1 يرجع، د. سعيد نبيل العشري، الأقنعة المسرحية (لعبة الدراما والحياة)، دار فنون للطباعة

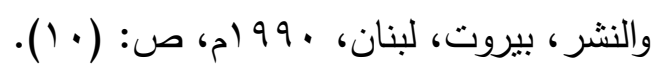

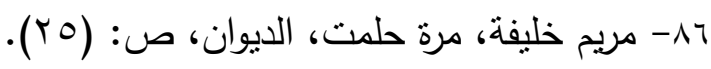

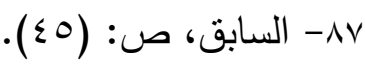

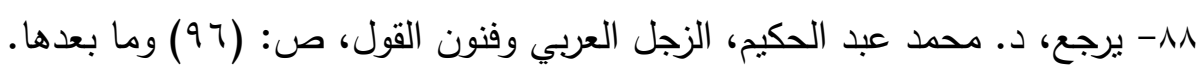

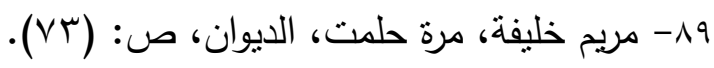

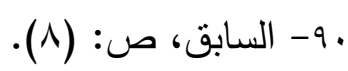

19- السابق، ص: (Y (I).

ra- السابق، ص: (ع 1). 